\title{
PENINGKATAN HASIL BELAJAR IPA MELALUI PENGGUNAAN MEDIA PEMBELAJARAN INTERAKTIF DI KELAS V
}

\author{
Ningsih \\ e-mail: inci_siahaan@yahoo.com \\ PGSD-FIP Universitas Negeri Jakarta
}

\begin{abstract}
Abstrak: Rendahnya efektivitas guru dalam membelajarkan dapat membuat siswa merasa kurang semangat dalam belajar sehingga hasil belajar siswa menjadi rendah. Penelitian ini bermaksud mengatasi masalah pembelajaran tersebut dengan mengunakan CD pembelajaran interaktif melalui penelitian tindakan kelas. Bertempat di SD Negeri 09 Pagi, Pademangan Barat, Jakarta Utara, penelitian ini dilaksanakan khusus untuk mata pelajaran IPA kelas V dengan jumlah 40 siswa, dalam bulan Oktober- Desember 2011. Media CD pembelajaran interaktif dipilih berdasarkan kondisi siswa yang lebih senang belajar dengan menggunakan media audiovisual. Pengumpulan data dilakukan dengan menggunakan lembar instrumen pemantau tindakan aktivitas guru dan siswa, instrumen tes, catatan lapangan, dan rekaman pembelajaran dalam bentuk foto. Setelah melalui tiga siklus, hasil penelitian menunjukkan hasil belajar dalam pokok bahasan alat pencernaan manusia meningkat secara bertahap sampai mencapai nilai ketuntasan belajar. Implikasi hasil penelitian ini adalah hasil belajar IPA yang diperoleh semakin tinggi jika pembelajaran dilakukan dengan menggunakan media CD pembelajaran interaktif karena dapat membuat siswa aktif dalam proses kegiatan pembelajaran.
\end{abstract}

Kata kunci: penelitian tindakan kelas, media pembelajaran interaktif, hasil belajar

\section{IMPROVEMENT OF LEARNING OUTCOMES IN SCIENCE UTILIZING INTERACTIVE LEARNING MEDIA}

\begin{abstract}
The low effectiveness of teachers in teaching makes students feel less enthusiasm in learning and their learning outcomes become low. The purpose of this research is to overcome the problem by utilizing interactive learning CD in a classroom action research. Taking place at SD Negeri 09 Pagi, Pademangan Barat, Jakarta Utara, this research was conducted in the fifth grade with 40 students on the topic of Human Digestive Organs, as from October through December 2011. The selection of interactive learning CD was based on the students' preference to learn using audiovisual media. Data were collected by using the monitoring instrument sheet activities of teacher and students, test instrument, field notes, and recording of the learning in the form of photographs. After three cycles, the research findings indicated gradual improvement of the students' learning achievement and passed the mastery learning level. The research implication is the science students' learning outcomes will improve using Interactive Learning Media CD as it can motivate the students learn actively.
\end{abstract}

Keywords: classroom action research, interactive learning media, learning outcome

\section{PENDAHULUAN}

Pendidikan IPA diharapkan dapat menjadi wahana bagi peserta didik untuk mempelajari diri sendiri dan alam sekitar, serta prospek pengembangan lebih lanjut dalam menerapkannya di dalam kehidupan sehari-hari. Dalam pelaksanaannya sendiri, pembelajaran IPA di sekolah dasar (SD) haruslah disesuaikan dengan tingkat perkembangan dan karakteristik peserta didik usia SD (6-12 tahun). Dalam mengajarkan IPA di SD membutuhkan banyak perhatian karena guru harus dapat menyediakan pengalaman belajar yang bermakna, menguasai materi dan memiliki strategi, metode, teknik, model, menetapkan, dan mengembangkan pendekatan, ataupun pemilihan media pembelajaran variatif yang dapat digunakan agar siswa dapat memahami dan menguasai materi dengan baik.

Berdasarkan pengamatan yang dilakukan pene-

Perspektif Ilmu Pendidikan - Vol. 25 Th. XVI April 2012 liti, kecenderungan belajar yang banyak ditemukan di kelas V SDN Pademangan Barat 09 Pagi Jakarta Utara, yang berasal dari luar diri siswa (eksternal), khususnya dalam pembelajaran IPA, ialah guru sebagai pelaksana pembelajaran belum optimal saat melaksanakan tugasnya dalam mengajar mata pelajaran IPA. Guru sering terjebak dalam kegiatan rutinitas yang membosankan. Kegiatan pembelajaran IPA masih didominasi dengan cara konvensional yaitu dengan metode ceramah, sedangkan siswa hanya duduk diam mendengarkan penjelasan guru. Guru cenderung berpatokan pada buku paket saja dan siswa jarang diberikan kesempatan untuk berinteraksi langsung dengan benda-benda konkret atau hal-hal yang berkaitan dengan pelajaran IPA dalam kehidupan sehari-hari.

Selain itu, guru juga tidak menggunakan media yang menarik sehingga banyaknya materi dan konsep yang harus diingat dan dihafalkan menimbulkan kejenuhan serta kebosanan pada siswa. Dengan kata lain, 
hanya guru yang berperan aktif dalam pembelajaran, sedangkan siswanya pasif.

Salah satu kekurangan guru lainnya dalam pembelajaran IPA adalah kurangnya persiapan mengajar sehingga dalam proses pembelajarannya guru hanya menyuruh siswa membaca materi, memberi ceramah seadanya, dan menyuruh siswa mengerjakan soal-soal latihan (Majid, 2007: 12). Perencanaan pembelajaran memainkan peran penting dalam memandu guru untuk melaksanakan tugas sebagai pendidik dalam melayani kebutuhan belajar siswanya (Majid, 2007: 22).

Berdasarkan hasil pengamatan peneliti, kecenderungan belajar yang juga banyak ditemukan di kelas V SDN Pademangan Barat 09 Pagi Jakarta Utara, yang berasal dari dalam diri siswa (internal), bahwa siswa kurang semangat dalam belajar IPA di kelas. Siswa sering mengerjakan pekerjaan rumah (PR) di sekolah. Selain itu, siswa juga cenderung lebih banyak menghabiskan waktu untuk pergi dan bermain di warung internet (Warnet) dan lebih suka menonton televisi (TV) dibandingkan harus mengerjakan PR atau soalsoal latihan IPA.

Selain rendahnya efektivitas guru dalam mengajar dan kurangnya semangat siswa dalam belajar, hal lain yang ditemukan peneliti di kelas V SDN Padema-ngan Barat 09 Pagi Jakarta Utara adalah rerata hasil belajar mata pelajaran IPA yang menunjukkan kemerosotan. Pada tahun ajaran 2008-2009, hasil ratarata Ujian Akhir Semester (UAS) IPA pada semester I masih cukup baik, yaitu nilai 70. Namun, pada tahun ajaran berikutnya, yaitu tahun ajaran 2009-2010, hasil rata-rata UAS IPA pada semester I mulai mengalami penurunan, menjadi nilai 69. Penurunan hasil ratarata UAS terlihat sangat signifikan pada hasil UAS semester I tahun ajaran 2010-2011. Nilai rata-rata UAS pada semester 1 tahun ajaran ini hanya 54, yang artinya jauh dari standar Kriteria Ketuntasan Minimal (KKM) sekolah, yaitu 70 untuk mata pelajaran IPA. Dengan demikian, dapat dikatakan bahwa nilai hasil belajar IPA di kelas V SDN Pademangan Barat 09 Pagi mengalami penurunan yang sangat drastis.

Hal ini menunjukkan bahwa proses pembelajaran belum berhasil karena hasil belajarnya masih rendah dan diperlukan perbaikan dalam proses pembelajaran agar dapat meningkatkan kemampuan pemahaman siswa, sehingga hasil belajarnya pun dapat meningkat kembali. Berdasarkan pengalaman dan fakta-fakta yang ada ditemukan diSDN Pademangan Barat 09 Pagi, peneliti sangat perlu mengadakan penelitian mengenai peningkatan hasil belajar IPA. Salah satu upaya yang dapat dilakukan untuk me- ningkatkan hasil belajar adalah dengan menggunakan media pembelajaran yang menarik.

Media pembelajaran IPA yang terdapat di SDN Pademangan Barat 09 Pagi Jakarta Utara sangatlah beragam, diantaranya Kotak Instrumen Terpadu (KIT) IPA, alat indera, sistem alat pernapasan ataupun peredaran darah, dan sebagainya. Namun, dalam kenyataannya, media pembelajaran tersebut jarang sekali bahkan tidak pernah digunakan oleh guru dan biasanya hanya dijadikan pajangan di sekolah.

Salah satu media yang dapat membantu peserta didik dalam memahami materi IPA adalah media Compact Disc (CD) pembelajaran interaktif. Dengan adanya komputer atau laptop, guru dapat mengoperasikan dan menayangkan materi dan konsep alat pencernaan manusia yang terdapat dalam media CD pembelajaran interaktif. Kondisi siswa yang lebih senang untuk menonton TV dapat disiasati dengan mengajak siswa untuk bermain sambil belajar yaitu dengan menonton dan mengoperasikan sendiri tayangan dari media CD pembelajaran interaktif. Penggunaan media ini juga sejalan dengan periode perkembangan anak SD yang masih dalam tahap operasional konkret.

Program media CD pembelajaran interaktif yang akan digunakan oleh peneliti dalam pembelajaran IPA adalah program akal interaktif dan ai-learn. Program akal interaktif dan ai-learn merupakan software yang disajikan dengan teknologi multimedia menggunakan animasi, suara, dan video sehingga akan sangat menarik perhatian siswa dalam pembelajaran. Pada penelitian ini, peneliti memilih seri anak pintar dengan tema alam dan teknologi pada program akal interaktif yang diproduksi oleh PT. Akal Interaktif, sedangkan pada program ai-learn peneliti memilih program materi khusus untuk anak kelas V semester 1 yang diproduksi oleh PT ai-learn Indonesia. Selain berisi materi pelajaran, program ini juga memuat game dan soal-soal yang berguna bagi pemahaman siswa.

Berdasarkan pada latar belakang masalah tersebut, maka permasalahan dalam penelitian ini dapat dirumuskan sebagai berikut.

(1) "Bagaimanakah penggunaan media CD pembelajaran interaktif dapat meningkatkan hasil belajar IPA di kelas V SDN Pademangan Barat 09 Pagi Jakarta Utara?",

(2) "Apakah penggunaan media CD pembelajaran interaktif dapat meningkatkan hasil belajar IPA di kelas V SDN Pademangan Barat 09 Pagi Jakarta Utara?".

\section{Kajian Teoretis}

\section{Hakikat Hasil Belajar IPA}

a. Pengertian Belajar

Perspektif Ilmu Pendidikan - Vol. 25 Th. XVI April 2012 
Belajar, menurut Djamara \& Zain, (2006: 1) adalah suatu kegiatan yang bernilai edukatif. Nilai edukatif ialah interaksi yang terjadi antara guru dengan anak didik. Interaksi ini dikatakan edukatif karena kegiatan belajar yang dilakukan, diarahkan untuk mencapai tujuan tertentu yang telah dirumuskan sebelum pembelajaran dilakukan.

Menurut Kamus Besar Bahasa Indonesia (KBBI, 2007:121), belajar memiliki arti "berusaha, berlatih untuk mendapatkan ilmu atau pengetahuan". Definisi ini memiliki pengertian bahwa belajar adalah sebuah kegiatan untuk mencapai kepandaian atau ilmu. Dengan belajar, manusia akan memperoleh kepandaian atau ilmu sehingga manusia tidak hanya menjadi tahu, tetapi juga memahami, serta dapat melaksanakan dan memiliki kepandaian, dan ilmu tersebut sebagai pengetahuan untuk memenuhi kebutuhannya dalam kehidupan sehari-hari.

Winkel, dalam Purwanto (2009: 39) mengemukakan bahwa belajar adalah aktivitas mental/psikis yang berlangsung dalam interaksi aktif dengan lingkungan yang menghasilkan perubahan-perubahan dalam pengetahuan, keterampilan, dan sikap. Menurut pengertian ini, perubahan itu diperoleh melalui usaha (bukan karena kematangan), menetap dalam waktu yang relatif lama, dan merupakan hasil pengalaman.

Sedangkan Skinner (dalam Angkowo \& Kosasih, 2007: 43) berpendapat bahwa "belajar adalah suatu proses adaptasi atau penyesuaian tingkah laku yang berlangsung secara progresif". Artinya, belajar adalah proses penyesuaian yang dilakukan seseorang dan di dalamnya terdapat tahapan-tahapan belajar yang berkesinambungan dan berlangsung secara progresif sehingga terjadi perubahan tingkah laku.

Berdasarkan uraian di atas, dapat disimpulkan bahwa belajar adalah suatu kegiatan edukatif untuk mendapatkan ilmu atau pengetahuan dengan cara berinteraksi aktif dengan lingkungan sehingga mencapai kepandaian serta perubahan dalam pengetahuan, keterampilan, dan sikap melalui proses adaptasi atau penyesuaian tingkah laku yang berlangsung secara progresif agar memperoleh perubahan tingkah laku yang relatif menetap sebagai hasil dari sebuah pengalaman.

\section{b. Pengertian Hasil Belajar}

Menurut Purwanto (2009: 44), hasil belajar dapat dijelaskan dengan memahami dua kata yang membentuknya, yaitu hasil dan belajar. Pengertian hasil (product) menunjuk pada suatu perolehan akibat dilakukannya suatu aktivitas atau proses yang mengakibatkan berubahnya input secara fungsional.
Dalam siklus input-proses-hasil, hasil dapat dengan jelas dibedakan dengan input akibat perubahan oleh proses. Begitu pula dalam kegiatan belajar mengajar, setelah mengalami belajar siswa akan berubah perilakunya dibanding sebelumnya.

Hal tersebut sejalan dengan pendapat yang dikemukakan oleh Winkel dalam Purwanto (2009: 44) bahwa hasil belajar adalah perubahan yang mengakibatkan manusia berubah dalam sikap dan tingkah lakunya. Belajar dilakukan untuk mengusahakan adanya perubahan perilaku pada individu yang belajar. Perubahan perilaku itu merupakan perolehan yang menjadi hasil belajar. Perubahan perilaku akibat kegiatan belajar mengakibatkan siswa memiliki penguasaan terhadap materi pengajaran yang disampaikan dalam kegiatan belajar mengajar untuk mencapai tujuan pengajaran.

Menurut Hamalik (2003: 30), hasil belajar adalah perubahan tingkah laku pada orang tersebut dari yang tidak tahu menjadi tahu. Aspek perubahan tingkah laku yang termasuk hasil belajar meliputi pengetahuan, emosional, pengertian, hubungan sosial, kebiasaan, jasmani, keterampilan, etis atau budi pekerti, apresiasi, dan sikap. Berdasarkan pengertian hasil belajar menurut Hamalik (2003), maka hasil belajar merupakan proses perubahan tingkah laku dari diri seseorang dari tidak tahu menjadi tahu dan akan tampak dari perubahan dalam salah satu atau beberapa aspek tingkah laku tersebut.

Menurut Purwanto (2009: 44), hasil belajar sendiri seringkali digunakan untuk mengetahui seberapa jauh seseorang menguasai bahan yang sudah diajarkan. Penguasaan bahan ajar yang sudah diajarkan merupakan sesuatu yang harus dimiliki siswa sebagai dasar atau pedoman untuk dapat menggali pengetahuan lebih lanjut. Penguasaan dasar ini dapat terlihat dari hasil belajar siswa. Hasil belajar siswa pada hakikatnya adalah perubahan tingkah laku seperti yang telah dijelaskan di uraian sebelumnya.

Bloom dalam Sudjana (2009: 22-23) secara garis besar membagi tingkah laku sebagai hasil belajar dalam pengertian yang luas mencakup bidang kognitif, afektif, dan psikomotoris. Ranah kognitif berkenaan dengan hasil belajar intelektual yang tediri dari enam aspek, yakni pengetahuan atau ingatan, pemahaman, aplikasi, analisis, sintesis, dan evaluasi. Ranah afektif berkenaan dengan sikap yang terdiri dari lima aspek, yakni penerimaan, jawaban atau reaksi, penilaian, organisasi, dan internalisasi. Ranah psikomotor berkenaan dengan hasil belajar keterampilan dan kemampuan bertindak, yakni gerakan refleks, keterampilan gerakan dasar, kemampuan perseptual, keharmonisan 
atau ketepatan, gerakan keterampilan kompleks, serta gerakan ekspresif dan interpretatif.

Ketiga ranah tersebut menjadi objek penilaian hasil belajar. Di antara ketiga ranah itu, ranah kognitiflah yang paling banyak dinilai oleh para guru di sekolah karena berkaitan dengan kemampuan para siswa dalam menguasai isi bahan pengajaran. Namun, Anderson dan Krathwohl merevisi taksonomi kognitif Bloom dari satu dimensi menjadi dua dimensi, yaitu dimensi proses kognitif (cognitive process) dan dimensi pengetahuan (types of knowledge).

Anderson mengklasifikasikan proses kognitif menjadi enam kategori, yaitu ingatan (remember), pemahaman (understand), aplikasi (apply), analisis (analyze), evaluasi (evaluate), dan kreativitas (create). Dimensi pengetahuan diklasifikasi menjadi empat kategori, yaitu pengetahuan faktual (factual knowledge), pengetahuan konseptual (conceptual knowledge), pengetahuan prosedural (procedural knowledge), dan pengetahuan metakognisi (metacognitive knowledge) (Thorir, 2008:1).

Pertama, kemampuan ingatan ialah kemampuan yang hanya meminta responden atau siswa untuk mengenal/mengetahui adanya konsep, fakta-fakta, istilah-istilah, definisi, gagasan, prinsip dasar tanpa harus mengerti atau menggunakannya. Siswa hanya dituntut untuk menyebutkan kembali atau menghafal saja. Kedua, kemampuan pemahaman ialah tingkat kemampuan yang menuntut siswa mampu memahami arti atau konsep, situasi serta fakta dengan fakta. Ketiga, kemampuan penerapan adalah kemampuan untuk memahami aturan, hukum, rumus dan menggunakannya dalam pemecahan masalah. Keempat, kemampuan analisis adalah kemampuan memahami sesuatu dengan menguraikannya ke dalam unsurunsur. Kelima, kemampuan penilaian adalah kemampuan membuat penilaian dan mengambil keputusan dari hasil penilaiannya. Keenam, kemampuan mencipta adalah kemampuan memahami dengan mengorganisasikan bagian-bagian ke dalam kesatuan.

Kingsley membagi hasil belajar menjadi tiga macam, yakni (a) keterampilan dan kebiasaan, (b) pengetahuan dan pengertian, (c) sikap dan cita-cita. Pendapat lain dikemukakan oleh Gagne. Ia membagi lima kategori hasil belajar, yakni (a) informasi verbal, (b) keterampilan intelektual, (c) strategi kognitif, (d) sikap, dan (e) keterampilan motorik (Sudjana, 2009: 22).

Penilaian hasil belajar adalah proses pemberian nilai terhadap hasil-hasil belajar yang dicapai siswa dengan kriteria tertentu. Berdasarkan uraian di atas, maka yang dimaksud hasil belajar adalah suatu perolehan siswa akibat dilakukannya suatu aktivitas atau proses belajar yang mengakibatkan perubahan dari tidak tahu menjadi tahu, baik sikap maupun tingkah lakunya yang meliputi pengetahuan, emosional, pengertian, hubungan sosial, kebiasaan, jasmani, keterampilan, etis atau budi pekerti, apresiasi, dan sikap. c. Faktor-faktor yang Mempengaruhi Proses dan Hasil Belajar

Secara umum, proses dan hasil belajar sangat dipengaruhi belajar oleh faktor-faktor tertentu, baik itu internal (dari dalam siswa), maupun eksternal(dari luar diri siswa). Faktor-faktor yang mempengaruhi proses dan hasil belajar menurut Munadi (2008) adalah sebagai berikut.

1). Faktor Internal

a) Faktor Fisiologis

Secara umum, kondisi fisiologis, seperti kesehatan yang prima, tidak dalam keadaan lelah dan capek, tidak dalam keadaan cacat jasmani, dan sebagainya, semuanya akan membantu dalam proses dan hasil belajar. Selain itu, kondisi saraf pengontrol kesadaran dan panca indera juga dapat berpengaruh pada proses pembelajaran.

b) Faktor Psikologis

Beberapa faktor psikologis yang berpengaruh terhadap hasil belajar yaitu intelegensi, perhatian, minat dan bakat, motif dan motivasi, dan kognitif dan daya nalar.

2). Faktor Eksternal

a) Faktor Lingkungan

Kondisi lingkungan, baik berupa lingkungan fisik atau alam dan lingkungan sosial juga mempengaruhi proses dan hasil belajar.

b) Faktor Instrumental

Faktor-faktor instrumental ini dapat berupa kurikulum, sarana dan fasilitas, dan guru. Faktorfaktor ini diharapkan dapat berfungsi sebagai sarana untuk tercapainya tujuan-tujuan belajar yang telah direncanakan.

\section{Pengertian Ilmu Pengetahuan Alam}

Salah satu ilmu yang ada dan selalu berkembang di dunia saat ini adalah Ilmu Pengetahuan Alam (IPA). Kata-kata Ilmu Pengetahuan Alam merupakan terjemahan dari kata-kata bahasa Inggris "Natural Science" yang secara singkat sering disebut Science. Natural artinya alamiah, berhubungan dengan alam atau bersangkut-paut dengan alam. Science artinya ilmu pengetahuan. Jadi, Ilmu Pengetahuan Alam (IPA) atau science itu secara harfiah dapat disebut sebagai ilmu yang mempelajari peristiwa-peristiwa yang terjadi di alam. Ilmu alam mempelajari benda-benda alam, di mana objeknya adalah benda-benda alam dengan hukum-hukum yang pasti dan umum, berlaku kapan 
pun di mana pun. Tingkat kepastian ilmu alam relatif tinggi mengingat objeknya yang konkret, karena hal ini ilmu alam lazim juga disebut ilmu pasti.

Suyoso (2008: 1) menyatakan bahwa IPA merupakan pengetahuan hasil kegiatan manusia yang bersifat aktif dan dinamis tiada henti-hentinya serta diperoleh melalui metode tertentu yaitu teratur, sistematis, berobjek, bermetode, dan berlaku secara universal. Secara garis besar, metode ilmiah terdiri dari dua kegiatan, yaitu observasi atau pengamatan dan juga eksperimen atau percobaan. Artinya IPA merupakan pengetahuan dari hasil kegiatan manusia yang diperoleh dengan menggunakan langkah-langkah ilmiah yang berupa metode ilmiah dan didapatkan dari hasil eksperimen atau observasi yang bersifat umum dan akan terus disempurnakan.

IPA merupakan produk dan proses yang tidak dapat dipisahkan. Produk IPA ialah berupa faktafakta, hukum-hukum, konsep-konsep, prinsip-prinsip, teori-teori, klasifikasi, struktur, dan lainnya. Sedangkan proses IPA ialah cara kerja memperoleh hasil tersebut yang biasanya terkandung cara kerja, sikap, dan cara berpikir kemajuan IPA yang pesat disebabkan oleh proses ini.

Proses pembelajaran IPA menekankan pada pemberian pengalaman langsung untuk mengembangkan kompetensi agar menjelajahi dan memahami tentang alam sekitar secara ilmiah. Pembelajaran IPA sebaiknya diarahkan untuk dilaksanakan secara ilmiah untuk menumbuhkan kemampuan berpikir dan berbuat agar dapat membantu peserta didik untuk memperoleh pemahaman yang lebih mendalam tentang alam sekitar.

Berdasarkan beberapa pendapat yang telah diuraikan di atas, dapatlah ditarik suatu pengertian, bahwa IPA atau sains adalah ilmu pengetahuan yang mempelajari peristiwa dan benda-benda alam yang terdiri dari produk (fakta-fakta, hukum-hukum, konsep-konsep, prinsip-prinsip, teori-teori, klasifikasi, struktur) dan juga proses (cara kerja, sikap, dan cara berpikir kemajuan IPA), diperoleh melalui metode ilmiah (observasi dan eksperimen), yang berguna untuk mengembangkan kompetensi dan pemahaman yang lebih mendalam tentang alam kehidupan sekitar secara ilmiah.

\section{Pengertian Hasil Belajar IPA}

Hasil belajar IPA adalah perubahan sikap dan tingkah laku siswa sebagai hasil dari pengalaman belajar IPA untuk mengembangkan pemahaman tentang alam sekitar dengan pembelajaran langsung terhadap sumber belajar dan dapat diukur dengan menggunakan tes.
Hasil belajar IPA yang dimaksudkan oleh peneliti ialah upaya memberikan nilai terhadap proses pembelajaran IPA yang dilakukan oleh guru untuk melihat sejauh mana keefektifan proses belajar dalam mencapai tujuan pembelajaran atau perubahan tingkah laku siswa dalam belajar IPA beserta isinya. Oleh sebab itulah, peneliti tidak hanya menilai produk (hasil belajar IPA) saja, tetapi juga menilai proses (cara kerja dan cara berpikir IPA). Hal ini disebabkan karena penilaian proses dan produk saling berkaitan satu sama lain.

Hasil belajar yang dilakukan pada penelitian ini mencakup ranah kognitif saja dan hanya dibatasi pada pengetahuan (C1), pemahaman (C2), dan penerapan (C3), dikarenakan siswa SD lebih cenderung memahami hal-hal yang konkret.

\section{Karakteristik Siswa Kelas V SD}

Perkembangan bukan merupakan suatu proses yang terputus-putus dan terpisah-pisah, melainkan suatu proses dinamis yang berlangsung terus-menerus. Perkembangan merupakan perubahan-perubahan psikologis/mental yang dialami individu dalam proses menjadi dewasa. Sedangkan pertumbuhan berarti perubahan-perubahan fisik/ biologis ke arah kemasakan fisiologis, yaitu organorgan tubuh yang dapat berfungsi secara optimal (Irwanto, 2002: 34-35). Pertumbuhan dan perkembangan berhubungan dengan perubahan struktur dan fungsi karakteristik manusia, yang terjadi dalam kemajuan yang mantap dan merupakan suatu proses kematangan. Baik peserta didik yang cepat ataupun lambat, memiliki kepribadian yang menyenangkan atau menggelisahkan, tinggi ataupun rendah, sebagian besar bergantung pada interaksi antara kecenderungan bawaan dan pengaruh lingkungan.

Pandangan menyeluruh tentang pertumbuhan dan perkembangan diberikan oleh Piaget, yaitu teori Perkembangan Intelektual yang sangat rinci. Piaget mengidentifikasikan tahapan perkembangan intelektual yang dilalui anak yaitu (a) tahap sensorimotorik usia 0-2 tahun, (b) tahap praoperasional usia 2-6 tahun, (c) tahap operasi nyata usia 7-11 atau 12 tahun, (d) tahap operasi formal usia 11 atau 12 tahun ke atas (Mulyasa, 2008: 51-52).

Tingkatan kelas di sekolah dasar dapat dibagi dua menjadi kelas rendah dan kelas atas. Kelas rendah terdiri dari tiga kelas, yaitu kelas satu (I), dua (II), dan tiga (III). Sedangkan kelas tinggi sekolah dasar terdiri dari tiga kelas juga, yaitu kelas empat (IV), lima (V), dan enam (VI). Di Indonesia, kisaran usia sekolah dasar berada di antara 6 atau 7 tahun sampai 12 tahun. Usia siswa pada kelompok kelas bawah, sekitar 6 atau 
7 tahun sampai umur 9 tahun, sedangkan kelas atas sekitar 9 atau 10 tahun sampai 12 tahun. Siswa kelas V SDN Pademangan Barat 09 Pagi Jakarta Utara sendiri merupakan anak yang sedang dalam masa pertengahan kanak-kanak, berada dalam kelompok kelas atas dan berusia sekitar 10-11 tahun. Artinya, berdasarkan penggolongan Piaget tesebut, siswa kelas 5 berada dalam tahap operasi nyata atau operasional konkret (concrete operational thought).

\section{Hakikat Media Pembelajaran}

Kata "media" berasal dari bahasa Latin dan merupakan bentuk jamak dari kata "medium" yang secara harfiah berarti "perantara atau pengantar". Dengan demikian, media merupakan wahana penyalur informasi belajar atau penyalur pesan (Djamarah \& Zain, 2006: 120). Pesan yang dimaksud di sini ialah pesan ajar yang disampaikan guru kepada siswa melalui proses komunikasi dalam proses pembelajaran. Pesan tersebut terlebih dahulu diproses oleh guru untuk disampaikan kepada siswa. Media menunjukkan fungsi atau perannya, yaitu mengatur hubungan yang efektif antara dua pihak utama dalam proses belajar, siswa, dan isi pelajaran (Arsyad, 2007: 3). Ringkasnya, media adalah alat yang digunakan untuk menyampaikan atau mengantarkan pesan-pesan pembelajaran.

Media mencakup alat-alat fisik yang dapat menyajikan pesan serta merangsang siswa untuk belajar. Menurut AECT, media adalah perangkat lunak (software) sebagai media pertama atau lambang/simbol yang berisi pesan atau informasi yang biasanya disajikan dengan menggunakan peralatan sebagai media kedua yaitu perangkat keras (hardware) sebagai sarana untuk dapat menampilkan pesan yang terkandung pada media tersebut (Munadi, 2008: 9). Media hendaknya dapat dimanipulasi, dapat dilihat, didengar, dan dibaca. Media digunakan untuk menumbuhkan sikap positif siswa terhadap materi dan proses belajar.

Kata "pembelajaran" merupakan padanan kata dari kata instruction. Pembelajaran berarti proses, cara, perbuatan mempelajari. Dalam pembelajaran yang ditekankan adalah proses belajar, maka usaha-usaha yang terencana dalam memanipulasi sumber-sumber belajar agar terjadi proses belajar dalam diri siswa disebut sebagai pembelajaran (Munadi, 2008: 9).

Subjek dalam pembelajaran berpusat pada peserta didik dan menurut Imron (1996), pembelajaran adalah aktivitas di mana guru dan pembelajar berinteraksi. Guru harus belajar dari aktivitas belajar siswa. Aktivitas belajar siswa harus dijadikan titik tolak dalam merancang pembelajaran. Menurut Johnson dalam Contextual Teaching and Learning, pembelajaran merupakan (1) perubahan potensi yang bersifat permanen dan terjadi sebagai hasil dari praktik/latihan yang keras dan (2) perubahan dalam watak dan kemampuan manusia, yang dapat diingat dan tidak semata-mata berasal dari proses pertumbuhan saja.

Pembelajaran dimaksudkan terciptanya suasana sehingga siswa belajar. Tujuan pembelajaran haruslah menunjang dan dalam rangka tercapainya tujuan belajar. Tujuan pembelajaran mengarahkan guru agar berhasil dalam membelajarkan siswa sementara unsur-unsur dinamis pembelajaran mendukung bagi tercapainya tujuan pembelajaran yang dilakukan oleh guru. Imron (1996: 43) berpendapat bahwa salah satu unsur dinamis dalam pembelajaran ialah alat bantu belajar dan upaya penyediaannya. Alat bantu belajar sangatlah mendukung bagi tujuan belajar siswa. Karena itu dalam pembelajaran hendaknya alat bantu pembelajaran yang ada harus digunakan semaksimal mungkin untuk dapat memperjelas bahan-bahan belajar yang dipelajari oleh siswa.

Berdasarkan uraian di atas, dapat diambil kesimpulan bahwa media pembelajaran adalah segala sesuatu yang digunakan dalam proses belajar dan berbentuk alat fisik yang dapat dimanipulasi, dilihat, didengar dan dibaca, berguna untuk menyampaikan pesan isi materi pelajaran serta dapat merangsang pikiran, perasaan, perhatian, dan kemauan dalam diri siswa sehingga terdorong terlibat dalam proses pembelajaran yang pada akhirnya siswa memiliki perubahan perilaku yang permanen dan potensi diri sebagai hasil aktivitas proses pembelajaran.

a. Fungsi Media Pembelajaran

Berikut ini merupakan penjabaran fungsi media pembelajaran menurut Munadi (2008: 9).

1). Fungsi media sebagai sumber belajar

Media pembelajaran berfungsi sebagai sumber belajar, yakni sebagai penyalur, penyampai, penghubung, dan lain-lain".Sumber belajar pada hakikatnya merupakan komponen yang meliputi pesan, orang, bahan, alat, teknik, dan lingkungan, yang mana hal itu dapat mempengaruhi hasil belajar siswa. Dengan demikian sumber belajar dapat dipahami sebagai segala macam sumber yang ada di luar diri seseorang (peserta didik) dan memungkinkan (memudahkan) terjadinya proses belajar. Dalam masa perkembangannya, anak akan memasuki dunia sosialnya yang tidak hanya mencakup orang atau subjek yang ada di lingkungan dekatnya, tetapi juga melalui saluran buku, film, televisi dapat menjadi sumber belajar yang sumber belajar bagi anak yang bersangkutan.

2). Fungsi semantik

Media memiliki kemampuan dalam menambah 
perbendaharaan kata (simbol verbal) yang makna atau maksudnya benar-benar dipahami anak didik (tidak verbalistik).

3). Fungsi manipulatif

a) Media dapat mengatasi batas-batas ruang dan waktu.

b) Media dapat mengatasi keterbatasan inderawi manusia.

4). Fungsi psikologis

a) Fungsi atensi: dapat meningkatkan perhatian siswa terhadap materi ajar.

b) Fungsi afektif: menggugah perasaan, emosi, dan tingkat penerimaan atau penolakan siswa terhadap sesuatu.

c) Fungsi kognitif: siswa dapat memperoleh dan menggunakan bentuk-bentuk representasi objek yang dihadapi, baik orang, benda, atau kejadian.

d) Fungsi imajinatif: dapat meningkatkan dan mengembangkan imajinasi siswa.

e) Fungsi motivasi: media dapat memotivasi siswa dengan cara membangkitkan minat belajarnya dan menimbulkan harapan.

5). Fungsi sosiokultural: media dapat mengatasi hambatan sosiokultural antarpeserta komunikasi pembelajaran.

b. Prinsip-Prinsip Media Pembelajaran

Sudjana (dalam Djamarah \& Zain, 2006: 127-128) mengemukakan beberapa prinsip pemilihan media pembelajaran yang dibagi ke dalam tiga kategori, diantaranya.

1). Menentukan jenis media dengan tepat; artinya guru memilih terlebih dahulu media manakah yang sesuai dengan tujuan dan bahan pelajaran yang akan diajarkan.

2). Menetapkan atau memperhitungkan subjek dengan tepat; artinya perlu diperhitungkan apakah penggunaan media itu sesuai dengan tingkat kematangan/kemampuan anak didik.

3). Menyajikan media dengan tepat; artinya teknik dan metode penggunaan media dalam pembelajaran haruslah disesuaikan dengan tujuan, bahan, metode, waktu, dan sarana yang ada.

4). Menempatkan atau memperlihatkan media pada waktu, tempat, dan situasi yang tepat. Artinya kapan dan dalam situasi mana pada waktu mengajar media digunakan.

\section{Hakikat Media CD Pembelajaran Interaktif}

Kata media berasal dari bahasa Latin medius yang secara harfiah berarti "tengah", "perantara", atau "pengantar". AECT (Association of Education and Communication Technology) (dalam Angkowo \&
Kosasih, 2007: 10) memberi batasan bahwa media merupakan segala bentuk saluran yang digunakan untuk menyampaikan pesan atau informasi. Pesan atau informasi yang dimaksud di sini ialah pesan materi pembelajaran dalam rangka komunikasi dan interaksi guru dan siswa dalam proses pembelajaran agar dapat merangsang pikiran, perasaan, perhatian, dan kemauan siswa sehingga dapat mendorong terjadinya proses pembelajaran pada diri siswa.

Selain itu, media dalam proses pembelajaran cenderung diartikan sebagai alat-alat fisik yaitu alatalat grafis, fotografis, atau elektronis untuk menangkap, memproses, dan menyusun kembali informasi visual atau verbal (dalam Angkowo \& Kosasih, 2007: 10). Alat-alat fisik tersebut digunakan untuk membantu proses penyampaian informasi dalam belajar agar siswa dapat mengerti gagasan atau ide guru sehingga proses pembelajaran dapat berjalan secara efektif dan efisien. Jadi, media adalah segala sesuatu yang berbentuk fisik yang digunakan untuk menyalurkan pesan materi pelajaran dan dapat merangsang pikiran, perasaan, perhatian, dan kemauan siswa sehingga terjadi proses pembelajaran dalam diri siswa.

Pembelajaran berarti menyampaikan pikiran atau ide yang telah diolah secara bermakna. Menurut pengertian ini penyampaian pikiran atau ide tersebut lebih mengarah kepada guru sebagai pelaku perubahan. Sadirman (dalam Warsita, 2008: 266) mengemukakan bahwa pembelajaran adalah usaha-usaha yang terencana dalam memanipulasi sumber-sumber belajar agar terjadi proses belajar dalam diri peserta didik. Pembelajaran berisi serangkaian peristiwa yang dirancang dan mendukung proses belajar peserta didik secara internal. Jadi, inti pembelajaran adalah upaya yang dilakukan oleh pendidik dalam menciptakan kondisi agar terjadi proses belajar dalam rangka mencapai tujuan pembelajaran pada diri peserta didik.

CD interaktif adalah sebuah cakram padat yang berbentuk piringan optikal yang digunakan untuk menyimpan data secara digital. Materi yang disimpan dalam CD interaktif ialah program multimedia yang merupakan kombinasi dari teks, grafik, sound, animasi, dan video. Penggabungan ini merupakan suatu kesatuan yang secara bersama-sama menampilkan informasi, pesan, atau isi pelajaran. Secara umum, manfaat yang dapat diperoleh dengan menggunakan CD interaktif memiliki beberapa kelebihan sebagai media pembelajaran, yaitu (1) interaktif, (2) memberikan iklim afeksi secara individual, (3) meningkatkan motivasi belajar, (4) memberikan umpan balik, dan (5) kontrol pada penggunanya (Munadi, 2008: 152-153).

Pada kelebihan pertama, interaktif artinya 
dipakai oleh siswa secara mandiri. Siswa dapat mengaplikasikan program yang ada di CD interaktif dan melibatkan indera dan organ tubuh, seperti telinga (audio), mata (visual), dan tangan (kinestetik) yang dengan perlibatan ini memungkinkan siswa untuk dapat mengerti informasi atau pesan pembelajaran. Pada kelebihan kedua, dengan adanya CD Interaktif, siswa dapat mendapatkan pemenuhan pengetahuannya karena pembelajaran akan lebih mandiri dan membuat iklim pembelajaran menjadi bersifat afektif yang akan melibatkan penggambaran ulang berbagai objek yang ada dalam pikiran siswa. Pada kelebihan yang ketiga, dengan adanya CD interaktif proses pembelajaran menjadi lebih menarik sehingga siswa akan terus termotivasi untuk belajar. Pada kelebihan yang keempat, dengan adanya CD interaktif siswa dapat langsung memiliki umpan balik (respon) terhadap hasil belajar yang dilakukan oleh peserta didik. Pada kelebihan yang terakhir, karena CD interaktif diprogram untuk pembelajaran mandiri, maka kontrol dan pengendaliannya sepenuhnya berada pada siswa. Siswa dapat mengoperasikan menu-menu khusus yang dapat diklik oleh siswa untuk memunculkan informasi berupa audio, visual maupun fitur lain yang diinginkan oleh siswa.

Berdasarkan uraian di atas, dapat disimpulkan bahwa media CD pembelajaran interaktif adalah sebuah cakram padat yang berbentuk piringan optikal yang berisi program multimedia yang merupakan kombinasi dari teks, grafik, sound, animasi, dan video yang bersifat interaktif dan digunakan dalam menyalurkan pesan materi pelajaran untuk merangsang pikiran, perasaan, perhatian, dan kemauan siswa agar terjadi proses pembelajaran dalam diri siswa, sehingga memiliki perubahan perilaku sebagai hasil tahapan-tahapan aktivitas belajar dalam mencapai tujuan pembelajaran.

Media CD pembelajaran interaktif menampilkan sebuah tampilan yang memungkinkan siswa tidak hanya sekedar membaca dan melihat gambar, tetapi juga membuat siswa dapat mendengar dan memberikan kesempatan kepada siswa untuk mengontrol laju kecepatan belajarnya sendiri juga sekuensi penyajian. Hal ini berarti bahwa penggunaan media CD pembelajaran interaktif sangat baik digunakan, karena siswa dapat memiliki pengalaman langsung dan melibatkan inderanya dalam melakukan dan mengoperasikan media CD tersebut secara langsung.

\section{Langkah-Langkah Penggunaan Media CD Pem- belajaran Interaktif dalam Pembelajaran IPA.}

Pelaksanaan pembelajaran IPA tentang Alat Pencernaan Manusia dengan media CD pembelajaran interaktif dilaksanakan dalam tiga tahap kegiatan yaitu (1) Persiapan sebelum menggunakan media, (2) Kegiatan selama menggunakan media, dan (3) Kegiatan tindak lanjut (Sadiman, 2007: 198).

a. Tahap persiapan sebelum menggunakan media

Pada tahap ini peneliti mengkaji Kurikulum Tingkat Satuan Pendidikan (KTSP) untuk mengetahui standar kompetensi dan kompetensi dasar yang harus dimiliki siswa, mengkaji silabus pembelajaran IPA kelas V guna membuat Rencana Pelaksanaan Pembelajaran (RPP), menyiapkan media pembelajaran, buku-buku penunjang, dan instrumen penilaian yang diperlukan.

b. Tahap kegiatan selama menggunakan media (pelaksanaan)

Pada tahap ini, peneliti melaksanakan proses pembelajaran sesuai perencanaan yang dibuat. Pelaksanaan pembelajaran dibantu oleh teman sejawat (guru) sebagai observer. Dalam penggunaan media, peneliti menjaga suasana ketenangan. Jika memungkinkan, ruangan jangan sampai digelapkan sama sekali. Hal tersebut bertujuan agar peneliti dapat menulis hal-hal yang penting dan perlu diingat. Peneliti juga wajib untuk memperhatikan poisisi berdiri dan kelantangan suara pada saat menjelaskan materi. Perintah-perintah yang diinstruksikan kepada murid hendaknya dilakukan dengan tenang.

c. Tahap kegiatan tindak lanjut

Maksud kegiatan tindak lanjut ialah untuk menjajali apakah tujuan pembelajaran telah tercapai. Selain itu, tindak lanjut ini juga untuk memantapkan pemahaman terhadap materi yang disampaikan melalui media CD pembelajaran interaktif. Pada tahap ini dilakukan penilaian baik penilaian hasil belajar maupun proses belajarnya.

\section{Hipotesis Tindakan}

Berdasarkan acuan teori rancangan alternatif atau desain alternatif intervensi tindakan yang dipilih, maka rumusan hipotesis tindakan dalam penelitian ini adalah dengan penggunaan media CD pembelajaran interaktif dapat meningkatkan hasil belajar IPA siswa di kelas V SDN Pademangan Barat 09 Pagi Jakarta Utara.

\section{METODE PENELITIAN}

\section{Metode}

Jenis penelitian ini adalah penelitian tindakan kelas yang memang berasal dari barat dikenal dengan istilah Classroom Action Research (CAR).

\section{Tempat dan Waktu}

Penelitian ini dilaksanakan di kelas V SDN Perspektif Ilmu Pendidikan - Vol. 25 Th. XVI April 2012 
Pademangan Barat 09 Pagi, yang beralamat di Jl. Budi Mulia RT 11/15, Pademangan Barat, Kecamatan Pademangan, Jakarta Utara. Penelitian ini dilaksanakan pada semester ganjil tahun ajaran 2011 - 2012. Penelitian dilaksanakan selama tiga bulan yaitu bulan Oktober sampai Desember tahun 2011.

\section{Desain Intervensi Tindakan (Rancangan Siklus Penelitian)}

Desain intervensi tindakan atau rancangan siklus penelitian ini menggunakan model Kemmis dan Taggart. Dengan menggunakan model ini apabila pada awal pelaksanaan tindakan ditemukan adanya kekurangan, maka perencanaan dan pelaksanaan tindakan perbaikan masih dapat dilanjutkan pada siklus berikutnya sampai target yang diinginkan tercapai.

Rancangan tersebut memiliki empat tahapan yang lazim digunakan, yaitu (1) perencanaan tindakan, (2) pelaksanaan tindakan, (3) pengamatan/pengumpulan data, (4) melakukan refleksi dan evaluasi yang bertujuan untuk mengetahui sejauh mana pencapaian hasil yang diharapkan untuk kemudian diadakan revisi untuk pengambilan keputusan perlu tidaknya tindakan pada siklus berikutnya.

\section{Subjek/Partisipan}

Subjek dalam penelitian ini adalah seluruh siswa kelas V SDN Pademangan Barat 09 Pagi, Kecamatan Pademangan, Jakarta Utara yang berjumlah 40 orang dimana siswa laki-laki berjumlah 23 orang dan siswa perempuan berjumlah 17 orang. Para siswa itu tercatat sebagai siswa-siswi kelas $\mathrm{V}$ tahun pelajaran 2011/2012. Sedangkan partisipan yang terlibat dalam penelitian ini adalah rekan sejawat yaitu bapak Taryono, S.Pd., MM., yang merupakan salah satu guru di SDN Pademangan Barat 09 Pagi, Jakarta Utara. Beliau bertindak sebagai mitra dalam membantu pelaksanaan penelitian ini.

\section{Tahapan Intervensi Tindakan}

Penelitian ini terdiri dari beberapa tahapan, yaitu (1) perencanaan, (2) pelaksanaan, (3) pengamatan, dan (4) refleksi, pada setiap siklusnya.

1. Perencanaan Tindakan (planning)

Berdasarkan permasalahan yang diperoleh, ditetapkan langkah-langkah perencanaan tindakan sebagai berikut.

1) Peneliti dengan observer mengadakan pertemuan untuk menentukan langkah-langkah yang harus dilaksanakan dalam penelitian ini.

2) Peneliti merencanakan skenario pembelajaran yang sesuai dengan kurikulum dan tingkat kemampuan awal siswa berdasarkan hasil kesepakatan bersama dengan observer, untuk menyusun skenario pembelajaran.

\section{Pelaksanaan Tindakan (Action)}

Peneliti melaksanakan proses belajar mengajar sesuai dengan yang direncanakan dalam Rencana Pelaksanaan Pembelajaran (RPP) dalam setiap siklusnya. Dalam penelitian ini juga melibatkan kolaborator sebagai observer dalam proses penelitian. Kolaborator di sini adalah rekan sejawat yang mengamati saat kegiatan pembelajaran berlangsung.

\section{Pengamatan (Observation)}

Kegiatan yang dilakukan dalam tahap ini, $o b$ server mengamati pelaksanaan pembelajaran dengan menggunakan lembar pengamatan. Observasi ini merupakan kegiatan yang dilakukan bertujuan untuk mengenali, merekam, dan mendokumentasikan setiap indikator dari proses dan hasil yang dicapai baik yang ditimbulkan oleh tindakan terencana maupun akibat sampingannya.

Observasi ini dilakukan untuk mengetahui kesesuaian antara pelaksanaan tindakan dengan rencana tindakan yang telah disusun sebelumnya, serta untuk mengetahui seberapa jauh pelaksanaan tindakan yang sedang berlangsung dapat menghasilkan perubahan yang diharapkan yakni meningkatkan hasil belajar siswa.

\section{Refleksi (Reflection)}

Setelah peneliti melakukan proses belajar mengajar, peneliti mengumpulkan dan menganalisis data hasil observer, baik peneliti maupun tim peneliti bersama-sama melakukan refleksi (merenungkan kembali proses belajar mengajar yang telah dilakukan).

Dalam proses kegiatan refleksi tersebut, antara peneliti dengan tim peneliti mengadakan diskusi dan tanya jawab, dengan tujuan untuk melakukan perbaikan pada proses pembelajaran bagi peneliti pada putaran berikutnya. Proses refleksi juga akan merupakan verifikasi data hasil pengamatan tim peneliti, sehingga akan diperoleh data-data yang sama dan tepat antara peneliti dengan tim peneliti.

Dari verifikasi data hasil pengamatan tersebut, akan diperoleh data yang akurat mengenai butir-butir manakah yang sudah muncul dan butir-butir manakah yang belum sepenuhnya muncul pada proses kegiatan belajar mengajar yang telah dilakukan oleh peneliti pada putaran pertama, dan sekaligus sebagai acuan untuk merencanakan tindakan baru dan melakukan perbaikan pada proses pembelajaran bagi peneliti pada putaran berikutnya.

\section{Hasil Intervensi Tindakan yang Diharapkan}

Pencapaian keberhasilan dari setiap tindakan yang dilaksanakan dalam pembelajaran IPA di kelas V SD dengan penggunaan media CD pembelajaran 
interaktif adalah adanya keterlibatan siswa dan guru secara aktif dalam proses pembelajaran tersebut. Faktor pencapaian keberhasilan setiap tindakan yang dilaksanakan dapat dilihat dari pelaksanaan hasil pembelajaran penggunaan media CD pembelajaran interaktif dan dikatakan berhasil jika.

1. Hasil belajar IPA siswa dalam pelaksanaan pembelajaran dapat meningkat dalam setiap siklusnya dan berada dalam rentangan baik.

2. Skor aktivitas guru dan siswa yang berupa pemantau tindakan sikap guru dan siswa selama proses pembelajaran dalam kelas dengan menggunakan media $\mathrm{CD}$ pembelajaran interaktif meningkat dan dalam rentangan baik.

Kriteria ketercapaian dalam penelitian ini yaitu nilai hasil belajar IPA dalam menyelesaikan soal pilihan ganda alat pencernaan manusia kelas V SDN Pademangan Barat 09 Pagi Jakarta Utara mencapai $75 \%$ dari jumlah siswa memperoleh nilai minimal 70. Jika nilai hasil belajar siswa dalam penyelesaian masalah mengenai alat pencernaan manusia belum mencapai nilai minimal 70 dari $75 \%$ jumlah siswa, maka penelitian belum dikatakan berhasil.

Selain itu, untuk mengetahui keberhasilan guru dalam pembelajaran menggunakan media CD pembelajaran interaktif, peneliti bersama observer telah menyiapkan lembar pemantau pelaksanaan pembelajaran. Jika peneliti telah menjalankan tugasnya sebesar $\geq 85 \%$ dari total skor 30 , maka kriteria keberhasilan telah dicapai.

\section{Data dan Sumber Data}

1. Data

Data yang diperoleh dalam penelitian ini berupa data hasil penelitian dan data pemantau tindakan penelitian.

a. Data Hasil Penelitian

Data hasil penelitian berupa tes tertulis latihan soal atau hasil mengerjakan tugas yang diberikan oleh guru. Dalam penelitian (research) merupakan data tentang variabel penelitian yaitu tentang hasil belajar siswa.

Data tersebut berguna untuk menganalisis penelitian tentang gambaran peningkatan hasil belajar dan data tentang pemberian tugas dalam proses kegiatan belajar mengajar.

b. Data Pemantau Tindakan Penelitian

Data pemantau tindakan (action) merupakan data yang digunakan untuk mengontrol kesesuaian pelaksanaan tindakan dengan rencana yang telah disusun. Data tersebut terdiri atas data proses berupa lembar instrumen pemantau tindakan atau lembar pengamatan guru yang melaksanakan pembelajaran.

\section{Sumber Data}

\section{a. Data Hasil Penelitian}

Sumber data hasil penelitian adalah hasil belajar siswa kelas $\mathrm{V}$ setelah belajar IPA dengan penggunaan media CD pembelajaran interaktif.

b. Data Pemantau Tindakan Penelitian

Data pemantau tindakan penelitian adalah proses kegiatan pada pembelajaran IPA dengan penggunaan media $\mathrm{CD}$ pembelajaran interaktif.

\section{Teknik Pengumpulan Data}

Teknik pengumpulan data yang digunakan untuk mendapatkan data penelitian dengan cara berikut. 1. Melalui proses

a. Data pemantau tindakan guru yang melaksanakan pembelajaran dalam bentuk lembar pemantau tindakan yang dilakukan observer (rekan sejawat) di SDN Pademangan Barat 09 Pagi Jakarta Utara.

b. Data penelitian tindakan tentang hasil belajar IPA dalam bentuk tes yang dilakukan oleh siswa untuk melihat seberapa jauh hasil belajar yang dicapai selama penelitian berlangsung.

c. Dokumentasi berupa foto yang diambil pada saat kegiatan pembelajaran berlangsung.

d. Catatan lapangan, yaitu catatan penelitian selama pelaksanaan berlangsung baik berupa kekurangan-kekurangan atau pun hal yang perlu ditambah dan dipertahankan.

2. Dari aspek evaluasi, yaitu hasil post test untuk melihat tingkat kemampuan siswa selama pelaksanaan penelitian tindakan tersebut. Instrumen yang digunakan dalam penelitian ini adalah.

a. Pengamatan terhadap aktivitas guru dan siswa.

b. Pengamatan hasil belajar siswa.

Dalam penelitan ini menggunakan dua variabel, yaitu media CD pembelajaran interaktif dan hasil belajar.

\section{Analisis Data}

Analisis data yang akan digunakan dalam penelitian ini adalah menganalisis lalu membandingkan hasil belajar siswa setiap siklus, dan membandingkan hasil belajar siswa pada tes awal dan akhir penelitian setelah itu menyimpulkan apakah terjadi perubahan/tidak setelah tindakan dilakukan. Analisis data dilakukan pada setiap kegiatan refleksi, yaitu tanya jawab dan diskusi antara peneliti/ pelaksana tindakan dengan observer.

Data yang dianalisis berupa hasil evaluasi siswa setiap akhir siklus, hasil instrumen pemantau tindakan yang telah diisi, dan catatan lapangan observer. 


\section{HASIL DAN PEMBAHASAN}

\section{Deskripsi Data Siklus I}

\section{Siklus I Pertemuan 1}

Hari/ Tanggal : Senin, 21 November 2011

Alokasi Waktu : 2 × 35 Menit

\section{Perencanaan Tindakan}

Pada tahap ini, peneliti meminta satu orang guru, yaitu guru kelas V, Bapak Taryono, S.Pd., MM. untuk menjadi observer. Peneliti dengan observer mengadakan pertemuan untuk menentukan langkahlangkah yang harus dilaksanakan dalam penelitian ini. Selain itu, peneliti juga merencanakan skenario pembelajaran yang sesuai dengan kurikulum dan tingkat kemampuan awal siswa berdasarkan hasil kesepakatan bersama dengan observer. Peneliti dan observer mendiskusikan materi pelajaran yang akan dituangkan ke dalam Rencana Pelaksanaan Pembelajaran (RPP), LKS, serta alat dan media yang diperlukan untuk proses kegiatan pembelajaran, diantaranya media CD pembelajaran interaktif, 5 unit laptop dan sebuah LCD projector. Media penunjang pembelajaran yang lain juga disiapkan yaitu gambar sistem pencernaan manusia tujuannya untuk mempermudah penyampaian pesan kepada siswa sehingga siswa lebih cepat memahami materi pembelajaran.

Selain menyiapkan RPP dan media yang akan digunakan, peneliti juga mempersiapkan instrumen pemantau tindakan yang akan diisi oleh observer untuk mengetahui efektivitas pembelajaran yang telah dirancang oleh peneliti dalam kegiatan pembelajaran dengan menggunakan media CD pembelajaran interaktif. 2. Pelaksanaan Tindakan dan Observasi

Pertemuan pertama pada siklus I dilaksanakan pada tanggal 21 November 2011, dengan menggunakan metode pembelajaran ceramah, tanya jawab, diskusi kelompok, penugasan, serta pengamatan visual dari program akal interaktif. Kegiatan yang dilakukan pada tahap ini adalah melaksanakan tindakan sesuai dengan perencanaan pembelajaran yang telah dibuat. Kegiatan pembelajaran yang dilakukan adalah sebagai berikut.

a. Kegiatan Awal (10 menit)

Sebelum kegiatan belajar dimulai, guru terlebih dahulu mengatur set tempat duduk secara berkelompok. Di bagian belakang kelas terdapat empat meja yang diatasnya telah tersedia laptop dan CD pembelajaran interaktif, serta di bagian depan kelas terdapat empat meja yang menghadap guru. Hal ini bertujuan agar empat kelompok yang di bagian belakang kelas dapat berkonsentrasi mengoperasikan CD pembelajaran interaktif yang sudah tersedia di meja masing-masing dan bagian depan kelas dapat konsentrasi menonton tayangan CD serta mendengarkan penjelasan guru.

Untuk mengawali pembelajaran, mula-mula guru mengucapkan salam, memimpin siswa berdoa sebelum mulai belajar, mengkondisikan kelas agar tertib, dan mendata kehadiran siswa. Guru juga melakukan apersepsi untuk mengetahui sejauh mana kemampuan awal siswa tentang materi alat pencernaan manusia kemudian guru menyampaikan langkah-langkah dan tujuan yang akan dicapai dalam proses pembelajaran. b) Kegiatan Inti (50 Menit)

Setelah menjelaskan kegiatan yang akan dilaksanakan, guru membagi siswa ke dalam beberapa kelompok kecil yang berjumlah 8 kelompok, dan satu kelompok terdiri dari 5 orang. Kemudian guru memperagakan kepada siswa cara membuka dan mengoperasikan CD pembelajaran interaktif dengan program akal interaktif mekemudiani layar LCD projector.

Setelah selesai memperagakan cara mengoperasikan CD pembelajaran interaktif, guru membagikan Lembar Kerja Siswa (LKS) kepada setiap kelompok. Pada saat membagikan LKS, guru juga menginstruksikan cara mengerjakan LKS tersebut.

Saat semua kelompok sudah menerima LKS, empat kelompok yang sudah berada di depan laptop langsung mengoperasikan CD pembelajaran interaktif. Siswa mengidentifikasi dan berdiskusi tentang fungsi dan proses alat pencernaan manusia. Semua hasil identifikasi dan diskusi dicatat dalam LKS yang telah dibagikan guru. Setiap kelompok diberi waktu 15 menit untuk melakukan pengamatan visual dari laptop yang dioperasikannya.

Setelah semua kelompok selesai mengoperasikan CD pembelajaran interaktif, guru menjelaskan secara garis besar proses pencernaan dengan bantuan gambar proses pencernaan manusia. Hal ini bertujuan agar siswa lebih memahami materi. Setelah mendengarkan penjelasan guru, siswa mendiskusikan hasil pengamatan dan diskusi LKS kemudian perwakilan masing-masing kelompok menyampaikan hasil diskusinya. Guru membimbing siswa dalam menyampaikan hasil diskusinya.

Setelah masing-masing kelompok menyampaikan hasil diskusi, guru memberikan kesempatan kepada kelompok lain untuk menanggapi hasil presentasi temannya, baik itu berupa pertanyaan maupun masukan.

Setelah perwakilan kelompok menyampaikan hasil diskusi, guru memberikan kesempatan kepada siswa untuk bertanya mengenai materi yang siswa belum mengerti kemudian guru bersama-sama dengan 
siswa menyimpulkan hasil diskusi.

c. Kegiatan Akhir (10 menit)

Siswa bersama guru menyimpulkan materi tentang fungsi dan proses alat pencernaan manusia. Kemudian guru memberikan tugas PR untuk mempelajari materi kembali fungsi dan proses alat pencernaan di rumah agar dapat mengerjakan soal evaluasi yang diberikan guru keesokan harinya. Guru menutup pelajaran dengan memotivasi siswa agar semangat mengikuti pelajaran selanjutnya.

\section{Siklus I pertemuan 2}

Hari / Tanggal : Selasa, 22 November 2011

Alokasi Waktu : $2 \times 35$ menit

a. Kegiatan Awal (10 menit)

Sebelum memulai pelajaran, guru memimpin doa untuk memulai pelajaran kemudian guru memeriksa kebersihan siswa dan juga kebersihan kelas. Setelah mengkondisikan kelas, guru melakukan tanya jawab tentang materi pelajaran pertemuan sebelumnya. Guru pun menyampaikan tujuan pembelajaran dan proses pelaksanaan pembelajaran hari ini, yaitu kegiatan tes formatif materi yang sudah dipelajari di pertemuan kemarin dengan cara mengisi lembar evaluasi. Guru pun menjelaskan bagaimana cara mengisi lembar evaluasi dengan benar.

b. Kegiatan Inti (45 menit)

Setelah menyampaikan tujuan pembelajaran hari ini dan cara mengisi lembar evaluasi, guru menjelaskan kembali garis besar proses pencernaan dengan bantuan gambar proses pencernaan manusia sedangkan siswa duduk di tempatnya masing-masing (tidak berkelompok).

Saat guru selesai menjelaskan materi, guru membagikan soal evaluasi kepada siswa. Masingmasing siswa menerima tiga lembar soal yang berisi 20 pilihan ganda. Guru memberikan waktu kepada seluruh siswa untuk mengerjakan soal evaluasi dalam waktu 30 menit. Setiap siswa diberi kesempatan bertanya kepada guru jika ada soal pilihan ganda yang belum jelas. Guru mengawasi selama pelaksanaan tes formatif. Selesai kegiatan evaluasi guru melakukan tanya jawab kepada siswa untuk mengetahui soal manakah yang mereka anggap sulit, sehingga dapat menjadi bahan refleksi dengan pengamat dalam pembuatan soal pada pertemuan selanjutnya.

c. Kegiatan Akhir (15 menit)

Guru menutup kegiatan pembelajaran dengan mengajak siswa untuk menyimpulkan kegiatan pembelajaran hari ini. Guru juga menginformasikan materi untuk pertemuan berikutnya, yaitu tentang makanan.

Pengamatan tindakan dilaksanakan ketika proses pembelajaran berlangsung. Observer (rekan sejawat), melakukan monitoring dengan cara mengobservasi peneliti yang sedang melakukan proses pembelajaran. Observer mengamati kegiatan selama berlangsungnya pembelajaran yang kemudian hasilnya juga dituangkan dalam bentuk catatan lapangan.

Setelah menggunakan media CD pembelajaran interaktif, hasil belajar siswa sudah baik walaupun belum mencapai target. Hasil belajar yang diperoleh dapat dilihat pada tabel 1 .

Tabel 1. Data Hasil Tes Hasil Belajar IPA “Alat Pencernaan Manusia” Kelas V Siklus I

\begin{tabular}{|c|c|c|c|}
\hline Siswa No. & Nilai & Siswa No. & Nilai \\
\hline 1 & 65 & 21 & 75 \\
\hline 2 & 60 & 22 & 80 \\
\hline 3 & 85 & 23 & 60 \\
\hline 4 & 70 & 24 & 70 \\
\hline 5 & 60 & 25 & 50 \\
\hline 6 & 70 & 26 & 80 \\
\hline 7 & 90 & 27 & 65 \\
\hline 8 & 60 & 28 & 75 \\
\hline 9 & 70 & 29 & 80 \\
\hline 10 & 60 & 30 & 60 \\
\hline 11 & 70 & 31 & 65 \\
\hline 12 & 80 & 32 & 90 \\
\hline 13 & 80 & 33 & 70 \\
\hline 14 & 80 & 34 & 70 \\
\hline 15 & 75 & 35 & 55 \\
\hline 16 & 80 & 36 & 85 \\
\hline 17 & 75 & 37 & 70 \\
\hline 18 & 70 & 38 & 70 \\
\hline 19 & 80 & 39 & 60 \\
\hline 20 & 80 & 40 & 70 \\
\hline \multicolumn{2}{|c|}{ Jumlah } & \multicolumn{2}{|c|}{2,860} \\
\hline \multicolumn{2}{|c|}{ Rata-rata } & \multicolumn{2}{|c|}{71,50} \\
\hline
\end{tabular}

Berikut ini adalah tabel 2 yang menunjukkan tingkat kemampuan hasil belajar IPA melalui penggunaan CD pembelajaran interaktif setelah pelaksanaan pada siklus I.

Tabel 2. Hasil Belajar IPA Siklus I melalui Penggunaan CD Pembelajaran Interaktif

\begin{tabular}{|c|l|c|c|}
\hline No & \multicolumn{1}{|c|}{ Jenis Data } & Jumalah & Persentase \\
\hline 1 & Nilai terendah & 50 & \\
\hline 2 & Nilai tertinggi & 90 & \\
\hline 3 & Nilai $<70$ & 12 & $30 \%$ \\
\hline 4 & Nilai $\geq 70$ & 28 & $70 \%$ \\
\hline 5 & Jumlah & 2,860 & \\
\hline & Rata - rata & 71,50 & \\
\hline
\end{tabular}

Perspektif Ilmu Pendidikan - Vol. 25 Th. XVI April 2012 
Dari tabel tersebut di atas menunjukkan bahwa persentase jumlah siswa yang memperoleh skor $<70$ sudah lebih rendah daripada yang memperoleh $\geq$ 70. Indikator keberhasilan dari penelitian ini adalah persentase siswa memperoleh skor $\geq 70$ minimal $75 \%$. Namun dalam jumlah siswa tersebut masih kurang. Berarti siklus pertama masih belum mencapai indikator keberhasilan karena baru mencapai 70\% dari target penelitian, yaitu $75 \%$.

3. Refleksi

Tujuan diadakannya refleksi antara peneliti dengan observer adalah untuk merenungkan kembali kegiatan pembelajaran yang telah dilakukan.

Adapun revisi yang harus dilakukan adalah: (1) guru harus mengarahkan siswa untuk dapat terlibat dan berinteraksi aktif dalam kegiatan pembelajaran, (2) guru harus memotivasi siswa untuk memusatkan pikiran dan perhatian untuk mengikuti materi pelajaran, (3) guru harus lebih dapat memotivasi siswa untuk berani dalam mengutarakan dan menanggapi pertanyaan, (4) guru harus lebih dapat membangun siswa untuk saling berinteraksi dan bekerja sama sebagai sebuah kelompok dengan baik, dan (5) guru harus lebih memaksimalkan penggunaan media CD pembelajaran interaktif dalam proses pembelajaran agar hasil belajar siswa dapat lebih meningkat di siklus selanjutnya.

4. Hasil Tindakan Siklus I (Pertemuan 1 dan Pertemuan 2)

Berdasarkan nilai rata-rata hasil pengamatan tindakan proses pembelajaran setelah diperiksa oleh guru sebagai peneliti dan dibantu oleh observer antara lain yang meliputi nilai rata-rata kelas tes hasil belajar IPA dengan nilai 71,50. Nilai siswa yang mencapai target dari indikator keberhasilan minimal 70 sebanyak 28 siswa atau 70\%, siswa yang memperoleh di bawah indikator keberhasilan sebanyak 12 siswa atau $30 \%$. Hasil belajar ini belum mencapai target karena target yang diperlukan adalah $75 \%$. Selanjutnya untuk instrumen pemantau tindakan guru dan siswa baru mencapai skor 119 dengan persentase instrumen sebesar 79,33\%.

Berdasarkan hasil intervensi tindakan di atas maka tindakan pelaksanaan pada siklus I ini belum optimal, tidak sesuai dengan target yang diharapkan. Maka peneliti dan observer memutuskan untuk melakukan perencanaan tindakan pembelajaran pada siklus selanjutnya yaitu siklus II. Tindakan pada siklus II merupakan hasil revisi dari siklus I dengan tujuan meningkatkan keterlibatan siswa dalam belajar baik secara emosi, sosial dan intelektualnya dan diharapkan hasil belajar siswa dapat meningkat sehingga berdampak positif terhadap kualitas pembelajaran secara keseluruhan.

\section{Deskripsi Data Siklus II}

\section{Siklus II Pertemuan 1}

Hari / Tanggal : Rabu, 30 November 2011

Alokasi Waktu : 2 × 35 Menit.

1. Perencanaan Tindakan

Pada tahap ini, peneliti telah berdiskusi dengan observer, untuk membicarakan permasalahanpermasalahan yang ditemukan pada siklus pertama, diantaranya masalah keaktifan siswa dalam pembelajaran baik secara individu maupun kelompok, proses pembelajaran secara keseluruhan, serta target nilai yang belum tercapai. Peneliti dan observer juga merencanakan skenario pembelajaran, materi pelajaran, RPP, LKS, serta alat dan media yang diperlukan untuk proses kegiatan pembelajaran. Media penunjang pembelajaran yang lain juga disiapkan, yaitu contoh menu makanan bergizi seimbang agar siswa lebih cepat memahami materi pembelajaran. Peneliti juga mempersiapkan instrumen pemantau tindakan yang formatnya sama dengan instrumen pemantau tindakan pada siklus pertama. Perencanaan yang akan dilakukan pada siklus II ini merupakan tindak lanjut dari siklus I.

2. Pelaksanaan Tindakan dan Observasi

Pertemuan pertama pada siklus II ini dilaksanakan pada tanggal 30 November 2011, dengan menggunakan metode pembelajaran yang sama saat di siklus I, yaitu ceramah, tanya jawab, diskusi kelompok, penugasan, serta pengamatan visual dari program akal interaktif. Kegiatan pembelajaran yang dilakukan adalah sebagai berikut.

a) Kegiatan Awal (10 menit)

Sebelum kegiatan belajar dimulai, guru terlebih dahulu mengatur set tempat duduk secara berkelompok. Pengaturan tempat duduk di siklus II ini sama seperti pada saat di siklus I, empat meja belakang tersedia laptop dan CD pembelajaran interaktif dan empat meja depan menghadap guru.

Untuk mengawali pembelajaran, mula-mula guru mengucapkan salam, memimpin siswa berdoa sebelum mulai belajar, mengkondisikan kelas agar tertib, dan mendata kehadiran siswa. Guru juga melakukan apersepsi mengenai materi siklus I yaitu alat pencernaan manusia serta menyampaikan langkah-langkah dan tujuan yang akan dicapai dalam proses pembelajaran.

b) Kegiatan Inti (50 Menit)

Setelah menjelaskan kegiatan yang akan dilaksanakan, guru mengarahkan siswa untuk duduk sesuai kelompok pada saat minggu kemudian (siklus 
I) kemudian guru memakaikan papan nama kepada ketua kelompok masing-masing.

Setelah memakaikan papan nama kelompok, guru memperagakan kepada siswa cara membuka dan mengoperasikan $\mathrm{CD}$ pembelajaran interaktif dengan program akal interaktif mengenai makanan melalui layar LCD projector.

Setelah memperagakan cara mengoperasikan CD pembelajaran interaktif, guru membagikan Lembar Kerja Siswa (LKS) kepada setiap kelompok.

Setelah menerima LKS, empat kelompok yang sudah berada di depan laptop mengoperasikan CD pembelajaran interaktif serta mengidentifikasi dan berdiskusi tentang tayangan makanan. Semua hasil identifikasi dan diskusi dicatat dalam LKS yang telah dibagikan guru.

Agar siswa lebih memahami materi, setelah semua kelompok selesai mengoperasikan CD pembelajaran interaktif, guru menjelaskan secara garis besar materi makanan dengan menunjukkan contoh menu makanan seimbang serta bahan-bahan makanan yang telah dipersiapkan guru.

Setelah mendengarkan penjelasan guru, siswa mendiskusikan hasil pengamatan dan diskusi LKS kemudian perwakilan kelompok menyampaikan hasil diskusinya. Guru membimbing siswa dalam menyampaikan hasil diskusinya.

Guru memberikan kesempatan kepada kelompok lain untuk menanggapi hasil presentasi temannya, baik itu berupa pertanyaan maupun masukan. Setelah perwakilan kelompok menyampaikan hasil diskusi, guru memberikan kesempatan kepada siswa untuk bertanya mengenai materi yang siswa belum mengerti kemudian guru bersama-sama dengan siswa menyimpulkan hasil diskusi.

c) Kegiatan Akhir (10 menit)

Siswa bersama guru menyimpulkan materi makanan. Kemudian guru memberikan tugas PR untuk mempelajari kembali materi makanan di rumah agar dapat mengerjakan soal evaluasi yang diberikan guru keesokan harinya. Guru menutup pelajaran dengan memotivasi siswa agar semangat mengikuti pelajaran selanjutnya.

\section{Siklus I pertemuan 2}

Hari / Tanggal : Kamis, 01 Desember 2011

Alokasi Waktu : $2 \times 35$ menit

a) Kegiatan Awal (10 menit)

Sebelum memulai pelajaran, guru memimpin doa untuk memulai pelajaran kemudian guru memeriksa kebersihan siswa dan juga kebersihan kelas. Setelah mengkondisikan kelas, guru melakukan tanya jawab tentang materi pelajaran pertemuan sebelum- nya. Guru pun menyampaikan tujuan pembelajaran dan proses pelaksanaan pembelajaran hari ini, yaitu kegiatan tes formatif materi yang sudah dipelajari di pertemuan kemarin dengan cara mengisi lembar evaluasi. Guru pun menjelaskan bagaimana cara mengisi lembar evaluasi dengan benar.

b) Kegiatan Inti (45 menit)

Setelah menyampaikan tujuan pembelajaran hari ini dan cara mengisi lembar evaluasi, guru menjelaskan kembali garis besar materi makanan dengan bantuan bahan-bahan makanan seperti yang guru lakukan pada hari sebelumnya. Posisi siswa duduk di tempatnya masing-masing (tidak berkelompok).

Saat guru selesai menjelaskan materi, guru membagikan soal evaluasi kepada siswa. Masingmasing siswa menerima tiga lembar soal yang berisi 20 pilihan ganda. Guru memberikan waktu kepada seluruh siswa untuk mengerjakan soal evaluasi dalam waktu 30 menit. Setiap siswa diberi kesempatan bertanya kepada guru jika ada soal pilihan ganda yang belum jelas. Guru mengawasi selama pelaksanaan tes formatif. Selesai kegiatan evaluasi, guru melakukan tanya jawab kepada siswa untuk mengetahui soal manakah yang mereka anggap sulit, sehingga dapat menjadi bahan refleksi dengan pengamat dalam pembuatan soal pada pertemuan selanjutnya.

c) Kegiatan Akhir (15 menit)

Guru menutup kegiatan pembelajaran dengan mengajak siswa untuk menyimpulkan kegiatan pembelajaran hari ini.

Setelah menggunakan media CD pembelajaran interaktif, hasil belajar siswa sudah baik walaupun belum mencapai target. Hasil belajar yang diperoleh dapat dilihat pada tabel 3 .

Tabel 3. Data Hasil Tes Hasil Belajar IPA “Makanan"Kelas V Siklus II

\begin{tabular}{|c|c|c|c|}
\hline Siswa No. & Nilai & Siswa No. & Nilai \\
\hline 1 & 65 & 16 & 80 \\
\hline 2 & 65 & 17 & 75 \\
\hline 3 & 90 & 18 & 75 \\
\hline 4 & 80 & 19 & 85 \\
\hline 5 & 60 & 20 & 80 \\
\hline 6 & 70 & 21 & 75 \\
\hline 7 & 90 & 22 & 80 \\
\hline 8 & 65 & 23 & 60 \\
\hline 9 & 70 & 24 & 70 \\
\hline 10 & 65 & 25 & 55 \\
\hline 11 & 70 & 26 & 75 \\
\hline 12 & 85 & 27 & 65 \\
\hline 13 & 80 & 28 & 80 \\
\hline 14 & 80 & 29 & 85 \\
\hline 15 & 70 & 30 & 60 \\
\hline
\end{tabular}

Perspektif Ilmu Pendidikan - Vol. 25 Th. XVI April 2012 


\begin{tabular}{|c|c|c|c|}
\hline Siswa No. & Nilai & Siswa No. & Nilai \\
\hline 31 & 75 & 36 & 90 \\
\hline 32 & 95 & 37 & 75 \\
\hline 33 & 80 & 38 & 80 \\
\hline 34 & 80 & 39 & 65 \\
\hline 35 & 60 & 40 & 70 \\
\hline \multicolumn{2}{|c|}{ Jumlah } & \multicolumn{2}{|c|}{74,375} \\
\hline \multicolumn{2}{|c|}{ Rata - rata } & \\
\hline
\end{tabular}

Berikut ini adalah tabel 4 yang menunjukkan tingkat kemampuan hasil belajar IPA melalui penggunaan CD pembelajaran interaktif setelah pelaksanaan pada siklus II.

Tabel 4. Hasil Belajar IPA Siklus II melalui Penggunaan CD Pembelajaran Interaktif

\begin{tabular}{|c|l|c|c|}
\hline No & \multicolumn{1}{|c|}{ Jenis Data } & Jumalah & Persentase \\
\hline 1 & Nilai terendah & 55 & \\
\hline 2 & Nilai tertinggi & 95 & \\
\hline 3 & Nilai $<70$ & 11 & $27,50 \%$ \\
\hline 4 & Nilai $\geq 70$ & 29 & $72,50 \%$ \\
\hline 5 & Jumlah & 2,975 & \\
\hline 6 & Rata - rata & 74,37 & \\
\hline
\end{tabular}

Dari tabel tersebut di atas menunjukkan bahwa persentase jumlah siswa yang memperoleh skor $<70$ pada siklus II ini sudah lebih rendah daripada yang memperoleh $\geq 70$. Indikator keberhasilan dari penelitian ini adalah persentase siswa memperoleh skor $\geq$ 70 minimal $75 \%$. Namun dalam jumlah siswa tersebut masih kurang. Berarti siklus kedua ini juga masih belum mencapai indikator keberhasilan karena baru mencapai $72,50 \%$ dari target penelitian, yaitu $75 \%$.

\section{Refleksi}

Tujuan diadakannya refleksi antara peneliti dengan observer adalah untuk merenungkan kembali kegiatan pembelajaran yang telah dilakukan. Adapun revisi yang harus dilakukan adalah: (1) guru harus mengarahkan siswa untuk dapat berbagi dengan temannya dalam mengoperasikan $\mathrm{CD}$ pembelajaran interaktif, (2) guru harus lebih dapat memotivasi siswa untuk berani dalam mengutarakan dan menanggapi pertanyaan selama proses pembelajaran berlangsung, (3) guru harus lebih dapat membangun siswa untuk saling bekerja sama sebagai sebuah kelompok dengan baik, dan (4) guru harus lebih memaksimalkan penggunaan media CD pembelajaran interaktif dalam proses pembelajaran agar hasil belajar siswa dapat lebih meningkat di siklus selanjutnya.

4. Hasil Tindakan Siklus II (Pertemuan 1 dan Pertemuan 2)

Berdasarkan nilai rata-rata hasil pengamatan tindakan proses pembelajaran setelah diperiksa oleh guru sebagai peneliti dan dibantu oleh observer antara lain yang meliputi nilai rata-rata kelas tes hasil belajar IPA dengan nilai 74,37 . Nilai siswa yang mencapai target dari indikator keberhasilan minimal 70 sebanyak 29 siswa atau $72,50 \%$, siswa yang memperoleh di bawah indikator keberhasilan sebanyak 11 siswa atau $27,50 \%$. Hasil belajar ini belum mencapai target karena target yang diperlukan adalah $75 \%$. Selanjutnya untuk instrumen pemantau tindakan, guru dan siswa baru mencapai skor 127 dengan persentase instrumen sebesar $84,67 \%$.

Berdasarkan hasil intervensi tindakan di atas maka tindakan pelaksanaan pada siklus II ini masih belum optimal dengan target yang diharapkan. Maka peneliti dan observer memutuskan untuk melakukan perencanaan tindakan pembelajaran pada siklus selanjutnya yaitu siklus III. Tindakan pada siklus III merupakan hasil revisi dari siklus I dan siklus II dengan tujuan meningkatkan keterlibatan siswa dalam belajar baik secara dan diharapkan hasil belajar siswa dapat meningkat.

\section{Deskripsi Data Siklus III \\ Siklus III Pertemuan 1}

Hari / Tanggal : Rabu, 07 Desember 2011

Alokasi Waktu : 2 × 35 Menit

1. Perencanaan Tindakan

Peneliti dan observer merencanakan skenario pembelajaran, materi pelajaran, RPP, LKS, serta alat dan media yang diperlukan untuk proses kegiatan pembelajaran. Media penunjang pembelajaran yang lain juga disiapkan, yaitu gambar-gambar penyakit yang menyerang alat pencernaan manusia yang ditampilkan melalui program Microsoft PowerPoint. Hal ini dilakukan agar siswa lebih cepat memahami materi pembelajaran. Peneliti juga mempersiapkan instrumen pemantau tindakan yang formatnya sama dengan instrumen pemantau tindakan pada siklus kedua. Perencanaan yang akan dilakukan pada siklus III ini merupakan tindak lanjut dari siklus II.

\section{Pelaksanaan Tindakan dan Observasi}

Pertemuan pertama pada siklus III ini dilaksanakan pada tanggal 07 Desember 2011, dengan menggunakan metode pembelajaran yang sama saat di siklus I dan II, yaitu ceramah, tanya jawab, diskusi kelompok, penugasan, serta pengamatan visual dari program ai Learn. Kegiatan pembelajaran yang dilakukan adalah sebagai berikut:

a) Kegiatan Awal (10 menit)

Sebelum kegiatan belajar dimulai guru terlebih dahulu mengatur set tempat duduk secara berkelompok. Pengaturan tempat duduk di siklus III ini sama seperti pada saat di siklus I dan II, yaitu empat meja 
belakang tersedia laptop dan CD pembelajaran interaktif dan empat meja depan menghadap guru.

Untuk mengawali pembelajaran, mula-mula guru mengucapkan salam, memimpin siswa berdoa sebelum mulai belajar, mengkondisikan kelas agar tertib, dan mendata kehadiran siswa. Guru juga melakukan apersepsi mengenai materi siklus II yaitu makanan serta menyampaikan langkah-langkah dan tujuan yang akan dicapai dalam proses pembelajaran. b) Kegiatan Inti (50 Menit)

Setelah menjelaskan kegiatan yang akan dilaksanakan, guru mengarahkan siswa untuk duduk sesuai kelompok pada saat minggu lalu (siklus II) kemudian guru memakaikan papan nama kepada ketua kelompok masing-masing.

Setelah memakaikan papan nama kelompok, guru memperagakan kepada siswa cara membuka dan mengoperasikan $\mathrm{CD}$ pembelajaran dengan program ai-Learn mengenai Kesehatan Alat Pencernaan melalui layar LCD projector.

Setelah memperagakan cara mengoperasikan CD pembelajaran interaktif, guru membagikan Lembar Kerja Siswa (LKS) kepada setiap kelompok. Pada saat mengoperasikan CD pembelajaran interaktif dan juga dalam mengisi LKS, siswa yang mengalami kesulitan dibantu dan dibimbing oleh guru.

Agar siswa lebih memahami materi, setelah semua kelompok selesai mengoperasikan $\mathrm{CD}$ pembelajaran interaktif, guru menjelaskan secara garis besar materi Kesehatan Alat Pencernaan dengan menunjukkan contoh gambar-gambar penyakit yang menyerang alat pencernaan manusia dengan menggunakan Microsoft PowerPoint yang telah dipersiapkan guru sebelumnya.

Setelah melihat penayangan dan mendengarkan penjelasan guru, siswa mendiskusikan hasil pengamatan dan diskusi LKS kemudian perwakilan kelompok menyampaikan hasil diskusinya. Guru membimbing siswa dalam menyampaikan hasil diskusinya.

Guru memberikan kesempatan kepada kelompok lain untuk menanggapi hasil presentasi temannya, baik itu berupa pertanyaan maupun masukan. Setelah perwakilan kelompok menyampaikan hasil diskusi, guru memberikan kesempatan kepada siswa untuk bertanya mengenai materi yang siswa belum mengerti kemudian guru bersama-sama dengan siswa menyimpulkan hasil diskusi.

c). Kegiatan Akhir (10 menit)

Siswa bersama guru menyimpulkan materi Kesehatan Alat Pencernaan. Kemudian guru memberikan tugas PR untuk mempelajari kembali materi kesehatan alat pencernaan di rumah agar dapat mengerjakan soal evaluasi yang diberikan guru keesokan harinya. Guru menutup pelajaran dengan memotivasi siswa agar semangat mengikuti pelajaran selanjutnya.

\section{Siklus III pertemuan 2}

Hari / Tanggal : Kamis, 08 Desember 2011

Alokasi Waktu : $2 \times 35$ menit

a) Kegiatan Awal (10 menit)

Sebelum memulai pelajaran, guru memimpin doa untuk memulai pelajaran lalu guru memeriksa kebersihan siswa dan juga kebersihan kelas. Setelah mengkondisikan kelas, guru melakukan tanya jawab tentang materi pelajaran pertemuan sebelumnya. Guru pun menyampaikan tujuan pembelajaran dan proses pelaksanaan pembelajaran hari ini, yaitu kegiatan tes formatif materi yang sudah dipelajari di pertemuan kemarin dengan cara mengisi lembar evaluasi. Guru pun menjelaskan bagaimana cara mengisi lembar evaluasi dengan benar.

b) Kegiatan Inti (45 menit)

Setelah menyampaikan tujuan pembelajaran hari ini dan cara mengisi lembar evaluasi, guru menjelaskan kembali garis besar materi kesehatan alat pencernaan dengan bantuan gambar-gambar penyakit yang menyerang alat pencernaan dengan menggunakan Microsoft PowerPoint sama seperti yang guru lakukan pada hari sebelumnya. Posisi siswa duduk di tempatnya masing-masing (tidak berkelompok).

Saat guru selesai menjelaskan materi, guru membagikan soal evaluasi kepada siswa. Setiap siswa menerima tiga lembar soal yang berisi 15 pilihan ganda. Guru memberikan waktu kepada seluruh siswa untuk mengerjakan soal evaluasi dalam waktu 30 menit. Setiap siswa diberi kesempatan bertanya kepada guru jika ada soal pilihan ganda yang mereka belum jelas. Guru mengawasi selama pelaksanaan tes formatif. Selesai kegiatan evaluasi guru melakukan tanya jawab kepada siswa untuk mengetahui soal manakah yang mereka anggap sulit, sehingga dapat menjadi bahan refleksi dengan pengamat.

c) Kegiatan Akhir (15 menit)

Guru menutup kegiatan pembelajaran dengan mengajak siswa untuk menyimpulkan kegiatan pembelajaran hari ini. Pengamatan tindakan siklus III ini juga dilaksanakan ketika proses pembelajaran berlangsung. Observer (rekan sejawat), Bapak Taryono S.Pd., MM., melakukan monitoring dengan cara mengobservasi peneliti yang sedang melakukan proses pembelajaran. Beliau mengamati pelaksanaan pembelajaran untuk kegiatan guru dan siswa dalam lembar Instrumen Pemantau Tindakan yang berisi 30 butir pernyataan untuk mengetahui sejauh mana kesesuaian 
pelaksanaan kegiatan dengan rencana pembelajaran yang telah disusun sebelumnya dan untuk mengetahui kualitas penggunaan media CD pembelajaran interaktif. Observer mengamati kegiatan selama berlangsungnya pembelajaran yang kemudian hasilnya juga dituangkan dalam bentuk catatan lapangan.

Setelah menggunakan media CD pembelajaran interaktif, hasil belajar siswa sudah baik dan sudah mencapai target. Hasil belajar yang diperoleh dapat dilihat pada tabel 5 .

Tabel 5. Data Hasil Tes Hasil Belajar IPA “Kesehatan Alat Pencernaan" Kelas V Siklus III

\begin{tabular}{|c|c|c|c|}
\hline Siswa No. & Nilai & Siswa No. & Nilai \\
\hline 1 & 86 & 21 & 93 \\
\hline 2 & 86 & 22 & 100 \\
\hline 3 & 100 & 23 & 66 \\
\hline 4 & 100 & 24 & 86 \\
\hline 5 & 80 & 25 & 60 \\
\hline 6 & 93 & 26 & 93 \\
\hline 7 & 100 & 27 & 86 \\
\hline 8 & 73 & 28 & 100 \\
\hline 9 & 93 & 29 & 100 \\
\hline 10 & 80 & 30 & 73 \\
\hline 11 & 86 & 31 & 93 \\
\hline 12 & 100 & 32 & 100 \\
\hline 13 & 93 & 33 & 93 \\
\hline 14 & 93 & 34 & 93 \\
\hline 15 & 100 & 35 & 66 \\
\hline 16 & 100 & 36 & 100 \\
\hline 17 & 100 & 37 & 100 \\
\hline 18 & 93 & 38 & 100 \\
\hline 19 & 100 & 39 & 73 \\
\hline 20 & 93 & 40 & 86 \\
\hline \multicolumn{2}{|c|}{ Jumlah } & \multicolumn{2}{|c|}{3,610} \\
\hline \multicolumn{2}{|c|}{ Rata - rata } & \multicolumn{2}{|c|}{90,25} \\
\hline
\end{tabular}

Berikut ini adalah tabel 6 yang menunjukkan tingkat kemampuan hasil belajar IPA melalui penggunaan CD pembelajaran interaktif setelah pelaksanaan pada siklus III.

Tabel 6. Hasil Belajar IPA Siklus III melalui Penggunaan CD Pembelajaran Interaktif

\begin{tabular}{|c|l|c|c|}
\hline No & Jenis Data & Jumlah & Persentase \\
\hline 1 & Nilai terendah & 60 & \\
\hline 2 & Nilai tertinggi & 100 & \\
\hline 3 & Nilai $<70$ & 3 & $7,5 \%$ \\
\hline 4 & Nilai $\geq 70$ & 37 & $92,50 \%$ \\
\hline 5 & Jumlah & 3,610 & \\
\hline 6 & Rata - rata & 90,25 & \\
\hline
\end{tabular}

Dari tabel tersebut di atas menunjukkan bahwa persentase jumlah siswa yang memperoleh skor $<70$ pada siklus III ini sudah sangat jauh lebih rendah daripada yang memperoleh $\geq 70$. Indikator keberhasilan dari penelitian ini adalah persentase siswa memperoleh skor $\geq 70$ minimal $75 \%$, dan dalam jumlah siswa tersebut ternyata telah tercapai. Berarti siklus ketiga sudah mencapai indikator keberhasilan yaitu mencapai $92,50 \%$ dari target penelitian, yaitu 75\%.

3. Refleksi

Hasil penelitian menunjukkan bahwa sebagian besar siswa telah mendapat nilai yang ditargetkan dalam konsep belajar tuntas. Pada siklus III ini siswa sudah tampak baik dan mandiri dalam mengikuti pelajaran, hasil pengamatan aktivitas guru pun baik, sehingga dapat disimpulkan bahwa penggunaan media CD pembelajaran interaktif dapat meningkatkan kualitas pembelajaran IPA di kelas III SD. Berdasakan hasil yang diperoleh, peneliti dan observer menyimpulkan bahwa tindakan penelitian sudah cukup pada siklus III.

4. Hasil Tindakan Siklus III (Pertemuan 1 dan Pertemuan 2)

Berdasarkan nilai rata-rata hasil pengamatan tindakan proses pembelajaran setelah diperiksa oleh guru sebagai peneliti dan dibantu oleh observer, antara lain yang meliputi nilai rata-rata kelas tes hasil belajar IPA dengan nilai 90,25. Nilai siswa yang mencapai target dari indikator keberhasilan minimal 70 sebanyak 37 siswa atau 92,50\%, siswa yang memperoleh di bawah indikator keberhasilan sebanyak 3 siswa atau 7,5\%. Hasil belajar ini sudah mencapai target karena target yang diperlukan adalah $75 \%$. Selanjutnya untuk instrumen pemantau tindakan guru dan siswa sudah mencapai skor 148 dengan persentase instrumen sebesar $98,67 \%$.

Berdasarkan hasil refleksi dan analisis data di atas maka tindakan pelaksanaan pada siklus III ini sudah optimal dengan target yang diharapkan sehingga penelitian dinyatakan berhasil.

\section{Pemeriksaan Keabsahan Data}

Pemeriksaan keabsahan data diperoleh dari hasil pengamatan oleh observer dalam proses pembelajaran pada setiap siklusnya. Hasil pengamatan tersebut didapat melalui instrumen tindakan kelas yang mencakup indikator aktivitas guru, aktivitas siswa serta kondisi siswa pada saat pembelajaran. Instrumen aktivitas guru dalam pembelajaran dengan menggunakan media CD pembelajaran interaktif terdiri dari 9 indikator dan 15 butir pernyataan sesuai dengan komponen pembelajaran media CD pembelajaran interaktif. Indikator aktivitas siswa terdiri dari 
9 indikator dan 15 butir pernyataan sesuai dengan komponen pembelajaran media CD pembelajaran interaktif.

Selain itu, pemeriksaan keabsahan data didapat dari analisis hasil belajar IPA dengan menggunakan media CD pembelajaran interaktif yang dapat dilihat dari aspek dan unsur-unsur pada tes hasil belajar IPA, observer memberikan penilaian terhadap aktivitas guru, aktivitas siswa dan aktivitas guru dan siswa dalam pembelajaran IPA dengan menggunakan media CD pembelajaran interaktif. Peneliti dan observer melakukan penilaian terhadap pelaksanaan pembelajaran dan dilengkapi dengan dokumen berupa foto saat pembelajaran.

Penelitian tindakan kelas ini menggunakan teknik triangulasi dan melalui persetujuan dosen ahli pada instrumen-instrumen yang digunakan untuk mengumpulkan data. Instrumen pemantau tindakan, test dan non tes diperiksa dan disetujui oleh para ahli melalui lembar persetujuan.

\section{Analisis Data}

\section{Data Hasil Peningkatan Hasil Belajar Siswa}

Data ini diperoleh berdasarkan pemberian evaluasi kepada siswa dengan memberikan soal PG sebanyak 20 butir pada siklus I dan II, serta sebanyak 15 butir pada siklus III. Data yang sudah diisi kemudian dikumpulkan untuk dihitung jumlah skor untuk masing-masing siswa. Penelitian dinyatakan berhasil apabila data hasil belajar siswa sudah mencapai persentase $75 \%$ dari jumlah siswa yang mencapai nilai minimal 70 , tetapi jika belum mencapai nilai yang ditargetkan, maka penelitian dilanjut ke siklus berikutnya. Berikut data yang diperoleh.

a. Data siklus I diperoleh persentase hasil belajar siswa yang mendapat $>70$ adalah sebesar $70,00 \%$. Pada siklus ini belum mencapai nilai yang ditargetkan, maka dilanjutkan ke siklus II.

b. Data siklus II diperoleh persentase hasil belajar siswa yang mendapat $>70$ adalah sebesar $72,50 \%$. Pada siklus ini belum mencapai nilai yang ditargetkan, maka dilanjutkan ke siklus III.

c. Data siklus III diperoleh persentase hasil belajar siswa yang mendapat $>70$ adalah sebesar $92,50 \%$. Pada siklus ini sudah mencapai nilai yang ditargetkan, maka penelitian dianggap berhasil dan penggunaan $\mathrm{CD}$ pembelajaran interaktif baik sekali untuk digunakan dalam proses pembelajaran. Untuk lebih jelasnya dapat dilihat pada tabel 7 .

Tabel 7. Persentase Hasil Belajar Siswa $>70$

\begin{tabular}{|c|c|c|}
\hline No & Siklus & Hasil Belajar \\
\hline 1 & Siklus I & $70,00 \%$. \\
\hline
\end{tabular}

\begin{tabular}{|c|c|c|}
\hline No & Siklus & Hasil Belajar \\
\hline 2 & Siklus II & $72,50 \%$. \\
\hline 3 & Siklus III & $92,50 \%$. \\
\hline
\end{tabular}

\section{Data Pemantau Tindakan}

Data pemantau tindakan adalah data yang diperoleh dari hasil pengamatan guru mengajar yang telah dilakukan oleh observer. Data yang berhasil diperoleh pada penelitian ini dari setiap siklusnya sebagai berikut.

a. Siklus I data persentase pelaksanaan indikator pembelajaran sebesar 79,33\% dengan skor 119 .

b. Siklus II data persentase pelaksanaan indikator pembelajaran sebesar $84,67 \%$ dengan skor 127 .

c. Siklus III data persentase pelaksanaan indikator pembelajaran sebesar 98,67\% dengan skor 148 .

\section{Interpretasi Hasil Analisis dan Pembahasan}

Interpretasi hasil analisis adalah adanya peningkatan hasil belajar IPA pada siswa kelas V selama III siklus. Pada siklus I, persentase hasil belajar siswa hanya mencapai $70,00 \%$. Saat di siklus ke dua terjadi sedikit kenaikan yaitu $72,50 \%$. Namun pada siklus III persentase belajar siswa meningkat menjadi $92,50 \%$. Hasil pada siklus ke III sudah mencapai target, maka penelitian dinyatakan berhasil.

Hasil pemantau tindakan pembelajaran menggunakan media CD pembelajaran interaktif selama III siklus, dapat disimpulkan bahwa pembelajaran yang dilakukan dengan menggunakan media $C D$ pembelajaran interaktif mengalami peningkatan yang sangat baik. Pada siklus I hanya mencapai 79,33\% dengan skor 119 , pada siklus II hanya mencapai $84,67 \%$ dengan skor 127, dan pada siklus ke III mencapai $98,67 \%$ dengan skor 148 . Terjadi peningkatan di setiap siklus menunjukkan bahwa peneliti bersama observer dapat menemukan pemecahan dari setiap masalah-masalah yang ditemukan di setiap siklus dan mendapatkan hasil yang optimal.

\section{Implikasi}

Implikasi penggunaan media $\mathrm{CD}$ pembelajaran interaktif dalam pembelajaran IPA adalah sebagai berikut.

Pertama, pembelajaran tentang alat pencernaan manusia sangat dibutuhkan bagi siswa karena akan sangat besar peranannya dalam kehidupan sehari-hari. Kedua, penggunaan media CD pembelajaran interaktif dalam pembelajaran IPA memberikan pengalaman bagi siswa untuk belajar secara interaktif dan melibatkan kemampuan intelektual, emosional, sosial, sehingga pemahaman siswa meningkat. Ketiga, terciptanya proses interaktif multiarah, yaitu antarsiswa dengan 
siswa, siswa dengan guru, dan siswa dengan media. Keempat, pembelajaran IPA melalui penggunaan media CD pembelajaran interaktif mendorong siswa untuk ingin tahu dan melatih kerjasama sehingga media ini tepat untuk digunakan oleh guru dalam proses pembelajaran. Kelima, penggunaan media CD pembelajaran interaktif dapat meningkatan hasil belajar IPA siswa khususnya materi alat pencernaan manusia.

\section{PENUTUP}

\section{Kesimpulan}

Pembelajaran dengan menggunakan media CD pembelajaran interaktif pada kelas V SD dalam pembelajaran IPA, dapat meningkatkan hasil belajar siswa karena tampilannya yang merupakan kombinasi dari teks, grafik, sound, animasi, dan video yang bersifat interaktif akan menarik perhatian siswa dan merangsang pikiran dan perhatian siswa agar terjadi proses pembelajaran dalam diri siswa. Selain itu, salah satu keunggulan lain media CD pembelajaran interaktif ialah menampilkan sebuah tampilan yang memungkinkan siswa tidak hanya sekedar membaca dan melihat gambar, tetapi juga membuat siswa dapat mendengar dan memberikan kesempatan kepada siswa untuk mengontrol laju kecepatan belajarnya sendiri. Hal ini membuat siswa dapat memiliki pengalaman langsung dan melibatkan inderanya dalam melakukan dan mengoperasikan media tersebut secara langsung, sehingga akan membangkitkan minat belajar siswa dan berdampak pada peningkatan hasil belajar IPA.

Berdasarkan analisis data, hasil belajar yang diperoleh pada siklus I mencapai nilai $>70$ sebanyak 28 orang $(70,00 \%)$, siklus II 29 orang $(72,50 \%)$, dan siklus III terjadi peningkatan drastis, yaitu sebanyak 37 siswa mendapatkan nilai $>70(92,50 \%)$. Hasil pengamatan selama pembelajaran pada siklus I menunjukkan bahwa total skor hasil observasi aktivitas guru dan siswa adalah 119 dengan persentase 79,33\%; siklus II, total skor 127 dengan persentase $84,67 \%$; dan pada siklus ke III mengalami kenaikan signifikan, total skor yaitu 148 dan persentase mencapai 98,67\%. Hasil analisis data diperoleh melalui tes pada setiap akhir siklus setelah diberikan tindakan, sedangkan untuk hasil data proses pembelajaran diambil oleh observer dengan menggunakan lembar observasi. Data yang diambil dalam lembar pengamatan berupa data pemantau tindakan guru dan siswa ketika pembelajaran dengan menggunakan media CD pembelajaran interaktif.

Penggunaan media CD pembelajaran interaktif dapat meningkatkan hasil belajar IPA dengan meng- gunakan langkah-langkah berikut: (1) guru membagi siswa ke dalam 8 kelompok; (2) guru menjelaskan cara membuka program CD pembelajaran interaktif yang ada dalam komputer secara umum; (3) guru membagikan lembar kerja berisi apa yang harus diamati dari tayangan CD pembelajaran interaktif; (4) ada empat kelompok siswa mengoperasikan CD pembelajaran interaktif secara langsung. Lalu, empat kelompok lainnya menunggu giliran mengoperasikan CD pembelajaran interaktif dengan mendengarkan penjelasan guru dengan bantuan LCD projector; (5) kelompok yang belum mendapat giliran mengoperasikan CD, mengamati dengan seksama penayangan CD pembelajaran interaktif dengan bantuan layar LCD Projector sedangkan kelompok yang sudah mendapat giliran mengoperasikan CD fokus kepada tayangan yang ada dihadapannya sambil mengerjakan LKS yang diberikan oleh guru; (6) setiap kelompok diberi waktu 15 menit untuk mengoperasikan CD pembelajaran interaktif sebelum bergantian dengan kelompok lain; (7) setelah semua kelompok selesai mengoperasikan CD pembelajaran interaktif, guru menjelaskan secara garis besar materi dengan media tambahan; (8) setelah mendengarkan penjelasan guru, siswa mendiskusikan hasil pengamatannya sehingga diperoleh kesimpulan materi; (9) perwakilan kelompok menyampaikan hasil diskusinya; (10) kelompok lain menanggapi hasil presentasi temannya; (11) guru memberi kesempatan bertanya bagi siswa yang menginginkannya, dan (12) siswa bersama guru menyimpulkan hasil diskusi.

Berdasarkan hasil analisis data hasil belajar dan instrumen pemantau tindakan, dapat dilihat bahwa.

1. Hasil belajar yang diperoleh pada siklus III ialah 92,50\%. Jika disesuaikan dengan rentang kriteria penilaian yang telah dibuat peneliti, nilai tersebut berada dalam kriteria baik sekali (90\%-100\%). Artinya, penggunaan media CD pembelajaran interaktif baik sekali digunakan untuk meningkatkan kualitas proses pembelajaran IPA. Hal ini ditunjukkan dengan meningkatnya tes hasil belajar IPA tentang alat pencernaan manusia.

2. Terdapat hubungan antara keberhasilan pembelajaran dengan pencapaian langkah-langkah operasional pembelajaran yang dirancang dalam penelitian tindakan kelas yang dilakukan dalam penelitian ini.

Dengan demikian, berdasarkan hasil penelitian yang telah dilakukan maka dapat disimpulkan bahwa penggunaan media CD pembelajaran interaktif dapat meningkatkan hasil belajar IPA siswa di kelas V SDN Pademangan Barat 09 Pagi Jakarta Utara. 


\section{DAFTAR PUSTAKA}

Angkowo, R. \& Kosasih, A. (2007). Optimalisasi media pembelajaran. Jakarta: Grasindo.

Arsyad, A. (2007). Media pembelajaran. Jakarta: PT. Raja Grafindo Persada.

Djamarah, S. B. \& Zain, A. (2006). Strategi belajar mengajar. Jakarta: PT. Rineka Cipta.

Hamalik, O. (2003). Proses belajar mengajar. Bandung: Bumi Aksara.

Imron, A. (1996). Belajar dan pembelajaran. Jakarta: Pustaka Jaya.

Irwanto. (2002). Psikologi umum. Jakarta: PT. Prenhallindo.

Majid, A. (2007). Perencanaan pembelajaran. Bandung: PT. Remaja Rosdakarya.

Mulyasa, H. E. (2008). Implementasi kurikulum tingkat satuan pendidikan: Kemandirian guru dan kepala sekolah. Jakarta: Bumi Aksara.

Munadi, Y. (2008). Media pembelajaran. Jakarta: GP Press.

Purwanto. (2009). Evaluasi hasil belajar. Yogyakarta: Pustaka Belajar.

Sadiman, A. S., dkk. (2007). Media pendidikan. Jakarta: Raja Grafind

Sudjana, N. (2009). Penilaian hasil proses belajar mengajar. Bandung: Remaja Rosda Kary

Thorir, M. (2008). Kompleksitas revisi taksonomi Bloom oleh Anderson dan Krathwohl. Diakses pada tanggal 15 November 2011 dari http://m-thohir. blogspot.com/2008/02/kompleksitas-revisitaksonomi-bloom.

Warsita, B. (2008). Teknologi pembelajaran. Jakarta: Rineka Cipta. 